NBER WORKING PAPER SERIES

THE EFFECT OF CORPORATE TAXES ON INVESTMENT AND ENTREPRENEURSHIP

\author{
Simeon Djankov \\ Tim Ganser \\ Caralee McLiesh \\ Rita Ramalho \\ Andrei Shleifer \\ Working Paper 13756 \\ http://www.nber.org/papers/w13756 \\ NATIONAL BUREAU OF ECONOMIC RESEARCH \\ 1050 Massachusetts Avenue \\ Cambridge, MA 02138 \\ January 2008
}

The authors are from the World Bank, Harvard University, World Bank, World Bank, and Harvard University, respectively. We are grateful to Mihir Desai for considerable help at the early stages of this project, to Fritz Foley and especially James Hines for help at the later stages, and to Joel Slemrod for extensive comments. We are also grateful to Robert Barro, Bruce Bolnick, Raj Chetty, Laurence Kotlikoff, Rafael La Porta, Gregory Mankiw, James Poterba, Lawrence Summers, and Matt Weinzierl for helpful comments. Shleifer thanks the Kauffman Foundation for support of this research, and Nicholas Coleman for excellent research assistance. The views expressed herein are those of the author(s) and do not necessarily reflect the views of the National Bureau of Economic Research.

NBER working papers are circulated for discussion and comment purposes. They have not been peerreviewed or been subject to the review by the NBER Board of Directors that accompanies official NBER publications.

(C) 2008 by Simeon Djankov, Tim Ganser, Caralee McLiesh, Rita Ramalho, and Andrei Shleifer. All rights reserved. Short sections of text, not to exceed two paragraphs, may be quoted without explicit permission provided that full credit, including $\odot$ notice, is given to the source. 
The Effect of Corporate Taxes on Investment and Entrepreneurship

Simeon Djankov, Tim Ganser, Caralee McLiesh, Rita Ramalho, and Andrei Shleifer

NBER Working Paper No. 13756

January 2008, Revised April 2009

JEL No. G38,H25

\begin{abstract}
$\underline{\text { ABSTRACT }}$
We present new data on effective corporate income tax rates in 85 countries in 2004 . The data come from a survey, conducted jointly with PricewaterhouseCoopers, of all taxes imposed on "the same" standardized mid-size domestic firm. In a cross-section of countries, our estimates of the effective corporate tax rate have a large adverse impact on aggregate investment, FDI, and entrepreneurial activity. For example, a 10 percent increase in the effective corporate tax rate reduces aggregate investment to GDP ratio by 2 percentage points. Corporate tax rates are also negatively correlated with growth, and positively correlated with the size of the informal economy. The results are robust to the inclusion of controls for other tax rates, quality of tax administration, security of property rights, level of economic development, regulation, inflation, and openness to trade.
\end{abstract}

Simeon Djankov

The World Bank

1818 H Street

Washington, DC 20433

sdjankov@worldbank.org

Tim Ganser

Department of Economics

Harvard University

Littauer Center

1805 Cambridge Street

Cambridge, MA 02138

tganser@fas.harvard.edu

Caralee McLiesh

The World Bank

1818 H Street

Washington, DC 20433

cmcliesh@worldbank.org

\author{
Rita Ramalho \\ The World Bank \\ 1818 H Street \\ Washington, DC 20433 \\ rramalho@worldbank.org \\ Andrei Shleifer \\ Department of Economics \\ Harvard University \\ Littauer Center M-9 \\ Cambridge, MA 02138 \\ and NBER \\ ashleifer@harvard.edu
}




\title{
The effect of corporate taxes on investment and entrepreneurship ${ }^{1}$
}

\author{
Fourth Draft, March 2009
}

Simeon Djankov, Tim Ganser, Caralee McLiesh, Rita Ramalho, Andrei Shleifer

\begin{abstract}
We present new data on effective corporate income tax rates in 85 countries in 2004. The data come from a survey, conducted jointly with PricewaterhouseCoopers, of all taxes imposed on "the same" standardized mid-size domestic firm. In a cross-section of countries, our estimates of the effective corporate tax rate have a large adverse impact on aggregate investment, FDI, and entrepreneurial activity. Corporate tax rates are correlated with investment in manufacturing but not services, as well as with the size of the informal economy. The results are robust to the inclusion of many controls.
\end{abstract}

\footnotetext{
${ }^{1}$ The authors are from the World Bank, Harvard University, World Bank, World Bank, and Harvard University, respectively. We are grateful to Mihir Desai for considerable help at the early stages of this project, to Fritz Foley and especially James Hines for help at the later stages, and to Joel Slemrod for extensive comments. We are grateful to Kevin Hassett and Aparna Mathur for sharing their data and helping us to understand the differences between their and our tax variables. We are also grateful to Robert Barro, Bruce Bolnick, Raj Chetty, Laurence Kotlikoff, Rafael La Porta, Gregory Mankiw, James Poterba, Lawrence Summers, Matt Weinzierl, the editor, and three anonymous referees for helpful comments. Shleifer thanks the Kauffman Foundation for support of this research, and Nicholas Coleman for excellent research assistance.
} 


\section{Introduction}

The effect of corporate taxes on investment and entrepreneurship is one of the central questions in both public finance and development. This effect matters not only for the evaluation and design of tax policy, but also for thinking about economic growth (see Barro 1991, DeLong and Summers 1991, and Baumol, Litan, and Schramm 2007).

Starting with Jorgenson (1963) and Hall and Jorgenson (1967), many public finance economists have addressed this topic. A small selection of important studies includes Summers (1981), Feldstein, Dicks-Mireaux and Poterba (1983), Auerbach (1983), King and Fullerton (1984), Slemrod (1990), Auerbach and Hassett (1992), Hines and Rice (1994), Cummins, Hassett, and Hubbard (1996), Devereux, Griffith, and Klemm (2002), and Desai, Foley, and Hines (2004b). Auerbach (2002), Gordon and Hines (2002), Hasset and Hubbard (2002), and Hines (2005) survey aspects of this literature. Generally speaking, this research finds adverse effects of corporate income taxes on investment, although studies offer different estimates of magnitudes.

In this paper, we present new cross-country evidence on the effects of corporate taxes on investment and entrepreneurship. The evidence comes from a newly constructed data base of corporate income tax rates for 85 countries in 2004 . We seek to contribute to the literature in four ways.

First, we use new data for a large cross-section of countries. Most cross-country studies focus on either some or all of the OECD countries (see especially King and Fullerton 1984 and Devereux et al. 2002, 2003), and hence do not provide much information about the developing world. Hassett and Mathur (2006) use a large data set of tax rates for 72 countries over 22 years to investigate the effects of taxes, including 
corporate taxes, on wages rather than investment. Their data come from the AEI International Tax Database, which relies on summaries of tax rates produced by accounting firms, including PricewaterhouseCoopers, as well as the International Bureau of Fiscal Documentation ${ }^{2}$. Hassett and Mathur have time series data, which we do not. On the other hand, we have more complete information on depreciation and the treatment of labor taxes in the calculation of corporate tax rates $^{3}$.

Second, we construct a new database of corporate (and other) tax rates that are comparable across countries. Our data, assembled jointly by the World Bank, PricewaterhouseCoopers, and Harvard University, come from a computation of all relevant taxes applicable to the same standardized domestic enterprise, called TaxpayerCo, operating in each country. In many instances, these rates differ sharply from statutory corporate tax rates. The methodology of computing taxes for a standardized enterprise may provide a different perspective on corporate tax rates than just working with the statutes, although it is necessarily limited by the representativeness of case facts. Furthermore, we do not collect information on taxes paid by individuals ${ }^{4}$.

Third, in addition to standard data on aggregate investment and foreign direct investment (FDI), we put together new data on entrepreneurship. These data come from the relatively new World Bank Entrepreneurship Survey, which seeks to produce comparable business registration data for a large number of countries. We use this survey to construct measures of business density and formal entry.

\footnotetext{
${ }^{2}$ PwC has previously published tax rates for multiple countries, which have been used by Hassett and Mathur and others. Their rates have also been published by the World Bank's Doing Business reports. These reports cover more countries than we do, but do not contain as detailed information as we use.

${ }^{3}$ The correlation between the rates we compute and the Hassett-Mathur rates is only about .5. We return to their measures later in the paper.

${ }^{4}$ We check the robustness of our results to the inclusion of personal tax rates, but do not pursue an integrated analysis of personal and corporate taxes (see, e.g., Auerbach 1979 and Graham 2003).
} 
Fourth, as pointed out by Davis and Henrekson (2004), corporate income taxes might differentially affect investment in different sectors, as well as influence the allocation of resources between the formal and the informal sector. To address these issues, we use the World Bank's Enterprise Surveys to construct separate machinery investment measures for manufacturing and services. We also use the Global Competitiveness Report estimates of the size of the informal sector. We then assess the impact of corporate taxes on investment in manufacturing and services separately, as well as on the size of the informal economy.

Research in public finance has developed elaborate constructs of corporate tax rates that are relevant to particular investment decisions. In some instances, statutory rates measure the correct marginal tax rates. Hall and Jorgenson (1967) started an extensive literature on how to compute the economically correct marginal tax rates using assessments of profitability of future projects. But average rates might also be relevant for investment decisions if firms are credit constrained or if they make discrete investment choices (Devereux and Griffith 2003). In this paper, we remain agnostic as to which is the correct rate, and present a variety of measures and their effect on investment.

The principal corporate income tax measure we use is the effective tax rate that TaxpayerCo pays if it complies with its country's laws, defined as the actual corporate income tax owed by the company relative to pre-tax profits. Unlike much of the literature, we can actually compute that rate under our case facts. Since TaxpayerCo is a new company, we compute both the $1^{\text {st }}$ year effective tax rate, and the 5-year tax rate taking account of the present value of depreciation and other deductions. Our data reveal a consistent and large adverse effect of corporate taxes on both investment and 
entrepreneurship. A 10 percentage point increase in the $1^{\text {st }}$ year effective corporate tax rate reduces the aggregate investment to GDP ratio by about 2 percentage points (mean is $21 \%$ ), and the official entry rate by 1.4 percentage points (mean is $8 \%$ ).

To check the robustness of our results, we consider several additional potential determinants of investment and entrepreneurship. These include other taxes, including additional taxes imposed on the firm as well as the VAT and the personal income tax, measures of the cost of tax compliance, estimates of tax evasion, security of property rights, economic development, regulation, trade openness, inflation, and seignorage. Some of these factors affect some measures of investment and entrepreneurship, but they do not eliminate the large adverse effect of corporate taxes.

Finally, our data enable us to ask, in a cross-country context, whether corporate taxes encourage debt as opposed to equity finance (see Modigliani and Miller 1958, Auerbach 1979, Miller 1977, Graham 1996, Mackie-Mason 1990, Desai, Foley, and Hines 2004a). We find a large and significant positive association between the effective corporate tax rate and the aggregate debt to equity ratio.

The next section of the paper describes our data. Section 3 presents summary statistics. Section 4 presents the basic results on corporate taxation, investment, and entrepreneurship. Section 5 concludes.

\section{Data}

We collect our data from PricewaterhouseCoopers accountants and tax lawyers. We describe a standardized business and ask them essentially to fill out its tax return, as well as to provide supporting information and relevant tax schedules. Two rounds of this 
exercise were conducted, in January 2005 and 2006. This paper uses data covering the tax system effective in fiscal year $2004^{5}$.

The sample consists of 85 countries covered by Djankov et al. (2002). It includes 27 high income, 19 upper-middle income, 21 lower-middle income, and 18 low income countries. In addition to 22 rich OECD countries, 10 are in East Asia, 17 are in Eastern Europe, 13 in Latin America, 6 in the Middle East, 14 in Africa, and 3 in South Asia.

The data are constructed using a standardized case study of a business called “TaxpayerCo.” TaxpayerCo is a taxable corporation operating in the most populous city in the country. It is liable for taxes charged at the local, state/provincial, and national levels. It is $100 \%$ domestically and privately owned and has 5 owners, none of whom is a legal entity. TaxpayerCo performs general industrial/commercial activities: it produces ceramic flower pots and sells them at retail. It does not engage in foreign trade or handle products subject to a special tax regime. Ceramic pots were chosen because they are made in every country, and face no industry-specific tax regime.

TaxpayerCo employs 60 people: 4 managers, 8 assistants and 48 workers ${ }^{6}$. All are nationals and were hired on January $1^{\text {st }}$. One of the managers is also an owner. Employees of the same hierarchical status earn the same wage. All employees are younger than 40 years and all workers are younger than 26 years. All employees worked and earned the same salary the year before and none of the employees is disabled. Managers became subject to social security taxes prior to 1993 while assistants and workers only became subject to social security taxes after 1993.

\footnotetext{
${ }^{5}$ The survey presents respondents with financial statements for calendar year 2004. We always consider the data for calendar year 2004, even when fiscal year is different from calendar year.

${ }^{6}$ Sixty employees is a somewhat arbitrary number for a mid-size firm, which was chosen because it is the world-wide average employment in firms in the World Bank’s Enterprise Survey.
} 
The company started operations on January $1^{\text {st }} 2004$. On the same date, it bought all the assets. It owns one plot of land, a building, machinery, one truck, 10 computers and other office equipment. The building is used for production, storage and offices. It has 10,000 square feet of floor space on a 6,000 square foot land plot. The machinery is classified as light machinery for tax purposes. The value of computer assets is equally divided between hardware and software. Other office equipment is composed of standard office tables, chairs, one copier, one fax machine, one scanner and 10 phones.

We created TaxpayerCo's financial statements as if TaxpayerCo were operating in a tax free world. All variables in these financial statements were simple multiples of the country's income per capita in local currency (from the World Bank). The statements as well as the case of the U.S. using the actual values are presented in Table 1. Panel A describes the balance sheet, and Panel B the profit and loss statement. The multiples were chosen to be typical for a mid-size manufacturing firm. We specified that TaxpayerCo keeps $50 \%$ of after-tax profits as retained earnings and distributes the other $50 \%$ as dividends. In a tax-free world, retained earnings are then half of pre-tax earnings (equal to 79 times GNI per capita per Table 1), or 39.5 times GNI per capita. However, the actual amount of retained earnings is a function of the tax system and, therefore, is not included in the pre-tax Table 1.

We sent these statements to the PricewaterhouseCoopers office in Washington, D.C., from which they were distributed to the country offices. One response was prepared per country. PwC respondents in each country calculated the taxes that TaxpayerCo must pay in its first year of operation. Respondents also provided the full 
tax schedules for corporate income taxes ${ }^{7}$, labor taxes ${ }^{8}$ for which the statutory incidence is on the employer, property tax, asset and capital tax, turnover tax, business license tax, financial transactions tax, but also VAT and sales taxes. Respondents further described all applicable deductions and exemptions. They informed us of the full depreciation schedules for all assets, so we could compute depreciation allowances for TaxpayerCo. Respondents also recorded the deductibility of advertising expenses, machinery repair expenses, interest expenses, and of each applicable tax. Taxes at all levels of government were included. Our analysis focuses on corporate income taxes, although we use the additional tax and compliance cost data provided by PwC for robustness checks ${ }^{9}$.

For each tax, PwC respondents described the frequency and the process for payment, e.g., whether the tax could be paid electronically or required payment in person. The time it took to prepare, file and pay TaxpayerCo’s taxes was also recorded.

All data thus collected was subsequently discussed and checked with PwC personnel in the sample countries ${ }^{10}$. The data was also double-checked with information provided by the International Bureau for Fiscal Documentation. Discrepancies were then addressed through further discussions with PwC country offices.

\footnotetext{
${ }^{7}$ All taxes levied on corporate income are considered corporate income taxes for the purposes of this analysis, regardless of the name given to them.

${ }^{8}$ All charges levied on labor for which the statutory incidence is on the employer are considered labor taxes, whether they are called labor taxes, social security contributions, or something else, whether they are requited or unrequited, and whether they are paid to a public or private agency. We try to unbundle the mandatory accident insurance contribution from the labor taxes. Wherever we can obtain information on the contribution rate for the mandatory accident insurance contribution, we do not include it in the labor taxes to be consistent across countries. Many countries only mandate that employers have an accident-atwork insurance in place for their employees, but we could not find rates applicable to TaxpayerCo.

${ }^{9}$ We do not have enough information to integrate personal income and dividend taxes with corporate income taxes. We do not consider minor taxes, such as waste collection and vehicle taxes. Taxes on real estate transactions and capital gains taxes are not included because they do not come up in the case facts. ${ }^{10}$ Data for the Kyrgyz Republic and Mongolia were provided by PwC’s Kazakhstan office.
} 


\section{Tax variables}

Table 2 describes the main variables. We start with the tax variables, and divide their presentation into three groups: corporate income tax measures, other tax measures, and tax administration measures. We compute three corporate income tax rate variables: the first is the traditional statutory corporate income tax rate, while the remaining two are based on the actual taxes owed by TaxpayerCo as computed from survey responses. Appendix A presents the values of tax variables for all of the sample countries.

1. Statutory corporate tax rate. This is the tax rate a company has to pay on marginal income assuming that it is in the highest tax bracket, taking into account federal, state, and local rates. We account for the deductibility of some taxes for the purposes of calculating the tax base. In Switzerland and the U.S., for example, state income taxes are deducted from the federal income tax base ${ }^{11}$.

2. $1^{\text {st }}$ year effective corporate tax rate. This is the actual first year corporate income tax liability of TaxpayerCo relative to pre-tax earnings (79 times GNI per capita per Table 1), taking account of all available deductions. Appendix B illustrates the exact steps used in the calculation of this tax variable, and the next, for the case of Argentina.

3. 5-year effective corporate tax rate. This rate takes account of actual depreciation schedules going 5 years forward. The numerator is the present value of actual corporate tax liabilities of TaxpayerCo over 5 years, where only depreciation

\footnotetext{
${ }^{11}$ It is possible that TaxpayerCo faces a lower statutory tax rate than the maximum. We computed the statutory corporate income tax rate applicable to TaxpayerCo. Worldwide, it is 1.5 percentage points lower on average than the maximum rate, but across countries is very highly correlated with the highest statutory rate. We have run our regressions using the statutory rate applicable to TaxpayerCo, and they are generally weaker than those for other rates. A plausible interpretation of this is that it is the maximum statutory rate that is relevant for aggregate investment, which is what we use as the dependent variable. We therefore do not discuss the marginal rate applicable to TaxpayerCo any further in the paper.
} 
deductions change over time. The denominator is the present value of pre-tax earnings, assumed to be the same every year. We discount both taxes and profits at 8 percent ${ }^{12}$.

The effective corporate tax rate, both in its $1^{\text {st }}$ year and 5-year versions, does not fully reflect all the complexities that public finance theory suggests are relevant to corporate decision-making (see, e.g., King and Fullerton 1984). Our measures have the advantage of extreme simplicity and transparency, and may plausibly correspond to what profit-maximizing entrepreneurs look at when they evaluate investments. We present the basic ingredients of the computation of corporate taxes for a large number of countries, to see whether, in their simplest form, they influence investment and entrepreneurship.

In addition to the corporate taxes, we use four other tax rates in our analysis, the first three of which come from our survey, and the last from other PwC data:

4. Labor tax. This is the sum of all labor-related taxes payable by TaxpayerCo, including payroll taxes, mandatory social security contributions, mandatory health insurance, mandatory unemployment insurance, and any local contributions that depend on the payroll or number of employees. The denominator is pre-tax earnings of TaxpayerCo. Because our research design focuses on firms and not on their workers (or shareholders), only taxes with statutory incidence on the employer are included. We use the first year of operations. We do not have data on taxes paid by individuals, even if they are withheld by TaxpayerCo.

5. Other taxes. This is the sum of all taxes payable by TaxpayerCo in the first year of operation that enter the profit and loss statement where the statutory incidence is on the firm, other than corporate income and labor tax. It is the sum of all property taxes,

\footnotetext{
${ }^{12}$ In our main calculation of the 5-year effective tax rate, we do not take inflation into account. However, in our robustness checks, we both control for inflation and consider the effect of non-indexation of depreciation deductions, emphasized by Auerbach and Jorgenson (1980).
} 
business license taxes, financial transactions and asset and capital taxes payable by TaxpayerCo. The denominator is pre-tax earnings of TaxpayerCo.

6. VAT and Sales Tax. This is the sum of all consumption tax rates for taxes payable or collected by TaxpayerCo, including the value added tax, the sales tax, the turnover tax, and any related surtaxes. 82 of the 85 countries in our sample have VAT. For countries that have multiple VAT rates, we use the rate applicable to TaxpayerCo, i.e., to ceramic goods. Only 5 countries in our sample have a sales tax collected by TaxpayerCo, and that is what we use.

7. Personal Income Tax. This is the highest bracket marginal personal income tax rate in 2004. We only include the tax at the national level. This tax rate, obtained from PwC and other sources, is used as a control; it does not come from the main survey.

In addition to these seven tax rates, we use two measures of the burden of tax administration. The first is the number of tax payments made by TaxpayerCo in a fiscal year. The tax payments indicator reflects the actual number of taxes paid, the method of payment, the frequency of payment, and the number of agencies involved for TaxpayerCo during the second year of operation. It covers payments made by the company on consumption taxes, such as sales tax or value added tax (which are traditionally withheld on behalf of the consumer), as well as profit, labor, property and other tax payments. Where full electronic filing is allowed, the tax is counted as paid once a year even if the payment is more frequent. In Hong Kong, TaxpayerCo pays 4 times per year; in Mali, it pays 60 times per year.

The second measure of tax administration is the time to comply, recorded in hours per year. The indicator measures the time to prepare, file and pay (or withhold) three 
major types of taxes: the corporate income tax, value added or sales tax, and labor taxes, including payroll taxes and social security contributions. Preparation time includes the time to collect all information necessary to compute the tax payable. If separate accounting books must be kept — or separate calculations must be made — for tax purposes, the time associated with these activities is included. Filing time includes the time to complete all necessary tax forms and make all necessary calculations. Payment time is the hours needed to make the payment online or at the tax office. When taxes are paid in person, the time includes delays while waiting. In Armenia, it takes TaxpayerCo 1120 hours per year to fulfill all tax requirements; in Ireland, it takes 76 hours per year.

\section{Outcome Variables}

We primarily analyze the effect of corporate taxes on aggregate investment and entrepreneurship. We use two measures of investment: gross fixed capital formation and Foreign Direct Investment, both as a percentage of GDP, from the World Bank Development Indicators. Foreign Direct Investment (FDI) is the net inflows of investment to acquire a lasting management interest (10 percent or more of voting stock) in an enterprise operating in an economy other than that of the investor. Although foreign firms in some countries receive tax holidays, those tend to be relatively short term, and the rates that apply to domestic firms are probably correlated with those on foreign ones. We use the average of the two investment to GDP ratios over $2003-2005^{13}$. We also check our findings on FDI using estimates from the OECD for a smaller sample.

\footnotetext{
${ }^{13}$ World Banks' FDI numbers include considerable financial flows. Also, to the extent that these are net inflows, they are lower for countries that make significant investments abroad, such as Ireland. Because Ireland is a strong outlier in the data, we tried to replace the World Bank value for Ireland with OECD value. Our results only became stronger.
} 
We also examine two measures of entrepreneurship: the number of business establishments and the rate of new business registration. These data are collected by the World Bank’s Entrepreneurship Survey from national business registries whenever possible, and other sources when not. For each country, the Survey measures the existing stock and the registration rate of limited liability corporations (or their equivalent in other legal systems). The total number of registered firms is available for more countries than the entry rate. The Survey seeks to assure comparability across countries, as well as to avoid shell corporations with no employees established for tax purposes. The data cover the period from 2000 to 2004. The business density measure is defined as the number of registered limited liability corporations per 100 members of the working-age population as of 2004; business registration (“entry”) is defined as the average 2000-2004 ratio of registrations over the number of limited liability corporations.

The Entrepreneurship Survey does not cover sole proprietorships. For example, there are 7.2 million registered businesses in the United States that employ at least one worker. Another 15.1 million businesses do not employ a single worker other than the owner. The latter are not included in the density measure. In many sample countries, such businesses are not required to register with the company registrar, making it impossible to collect comparable data. They also usually face a different tax regime.

The fact that we use aggregate measures of investment and entrepreneurship leads to two conceptual problems. First, the rates we compute might be different from those faced by firms undertaking the bulk of aggregate investment (which are surely older and larger). Presumably, if the tax rates facing the largest firms were uncorrelated with those we compute, we would find nothing in our data. 
Second, many entrepreneurial firms might be smaller than TaxpayerCo, and not even organized as corporations, which would again point to a mismatch between our tax and entrepreneurship variables (see for example Goolsbee 1998). We have gone back and checked whether the tax measures we compute apply to other legal forms. Here we summarize what we have found; see Appendix C for details. For 50 of the 85 countries in the sample, we could confirm that the answer is yes. We have verified that our results on the effects of taxes hold in this sub-sample, and are similar to those for the whole sample. For another 19 countries, tax treatment of TaxpayerCo might differ depending on its legal status. We do not have the ability to make tax computations for alternative organizational forms for these 19 countries. Our results for these 19 countries only hold for FDI, which is indeed concentrated in the corporate sector. Finally, for 16 countries, we could not verify whether the same tax rules apply to other legal forms, but our basic results actually hold for that sub-sample, especially for the effective tax rates. It is best to interpret our evidence, then, as applying to investment and entrepreneurship by limited liability companies.

In addition to looking at the aggregate measures of investment and entrepreneurship, we consider the effects of corporate taxes on investment in manufacturing and services separately. Corporate taxes might reduce investment in manufacturing because most manufacturing firms operate in the formal sector, but shift activity from the formal to the informal sector in services, where informality is more prevalent (Davis and Henrekson 2004). It turns out that sectoral investment data are difficult to obtain for most countries ${ }^{14}$. Accordingly, we built up limited manufacturing

\footnotetext{
${ }^{14}$ There is some data from the United Nations, but we had difficulty making sense of the numbers.
} 
and services investment variables from the World Bank’s Enterprise Surveys, which survey formal firms with more than 5 employees in many countries.

To construct the investment numbers (for manufacturing and services in each country separately), we compute the median over all the firms with available data of “Purchases of New Machinery and Equipment” as a percentage of the establishment's “Total Sales.” This is a much narrower measure than aggregate investment, since it does not include other kinds of private investment or public investment. We use the median because there are many outliers in these data ${ }^{15}$. We have been able to construct these sectoral investment numbers for 32 countries for manufacturing and 20 for services.

In addition, we use an estimate of the size of the informal sector as a percentage of the total economy from the Global Competitiveness Report for 2005-2006 and 20062007. Several additional measures of the informal economy are available. A prominent estimate is Schneider's (2005), but it is computed using the ratio of tax collections to GDP. One can also construct estimates using Enterprise Surveys (La Porta and Shleifer 2008), but these are based on tax evasion. The advantage of the Global Competitiveness Report estimates is that they are not directly influenced by tax variables.

Finally, we use the average debt to equity ratio from the IMF. The IMF uses international financial databases of publicly traded companies to compute these averages from these national samples of traded firms.

\section{Control Variables}

We are principally interested in the effects of our four measures of corporate income tax on investment and entrepreneurship. Since we estimate simple cross-country

\footnotetext{
${ }^{15}$ Similar results obtain if we eliminate $10 \%$ of highest and lowest observations, and take the mean.
} 
regressions, there is always a risk that the correlations we document are spurious. To partially address this risk, we control for many factors in the regressions. These include the additional tax and tax compliance variables described above, but also other variables. We define those in Table 2, but summarize the economic issues here.

First, since our sample is dominated by developing countries, tax enforcement might be an important factor influencing investment. We use an estimate of the magnitude of tax evasion from the 2001-2002 Global Competitiveness Report. This measure is available for 64 countries, and is constructed independently of the tax rates. Second, one might worry that the overall quality of institutions affects investment and entrepreneurship. To address this concern, we control in the robustness checks for lagged per capita income and the property rights index from the Heritage Foundation. Third, recent research suggests that government regulations, such as those of entry (Djankov et al. 2002) and labor markets (Botero et al. 2004), affect investment and entrepreneurship ${ }^{16}$. We check the robustness of our results to the inclusion of these variables. Fourth, theory predicts that inflation might influence investment, partly through its impact on the cost of capital (Auerbach and Jorgenson 1980), and partly because the government might use seignorage as a substitute for taxes. To get at these issues, we control for the average 10-year inflation as a measure of long-run inflation, as well as for seignorage as a share of GDP. Finally, a country's openness to trade may influence investment and FDI; we check if it does.

\footnotetext{
${ }^{16}$ Examples of studies examining the effects of these measures of regulation on unemployment, labor reallocation, investment, and firm entry include Alesina et al. 2005, Haltiwanger et al. 2006, Klapper et al. 2006, and Ciccone and Papaioannou 2006.
} 


\section{A look at the data}

Table 3 presents the means of tax, tax administration, investment, entrepreneurship, and other outcome variables by income group. Several interesting findings emerge from these data. First, the world-wide average statutory corporate tax rate is about $29 \%$, and does not vary much across income groups. Nonetheless, there is large variation among countries. The statutory rate is $12.5 \%$ for Ireland, $15 \%$ for Latvia, Lithuania, and Lebanon, and over $40 \%$ for Pakistan, Japan, and the United States.

Second, in our sample, the world average $1^{\text {st }}$ year effective corporate tax rate, at $17.5 \%$, is $11.5 \%$ lower than the average statutory tax rate. Upper middle income countries have lower $1^{\text {st }}$ year effective rates than other groups, but otherwise variation across income groups is small. Again, there is significant variation among countries. In the first year of operation, TaxpayerCo faces zero effective corporate tax rate in Hong Kong and Mongolia, but 31\% in Pakistan and nearly 40\% in Bolivia.

Third, the 5-year effective corporate tax rate is only about 2 percentage points higher than the first year one, on average, with similar patterns across income groups. We no longer have zero rates, but Mongolia has 6.6\% and Lithuania 7.3\%.

Our data are probably least appropriate for measuring the labor tax, since we have data on taxes paid by firms but not by individuals. At the corporate level, the world-wide labor tax is around $15 \%$, with low income countries having somewhat lower rates. Other taxes are under $2 \%$ on average, and do not vary significantly by income level. However, they are as high as $17.6 \%$ in Bolivia and 14.5\% in Argentina.

The combined VAT and sales tax rate averages at $17 \%$, and does not vary much across income groups. It hits the low of zero in Hong Kong, and the high of $73.5 \%$ in 
Brazil, although the second highest country is Hungary at 27.2\%. The highest personal income tax rate averages $33.5 \%$ in the world, and is sharply higher in the rich than in the middle income countries. The rate is as high as 60\% in Vietnam and 59\% in Denmark, and as low as zero in Uruguay and $11.5 \%$ in Switzerland.

Our measures of tax administration for TaxpayerCo vary hugely by income level. The average annual number of all corporate tax payments is 35, ranging from 16 for high income countries to 48 for lower middle income countries, and 44 for poor countries. Norway has 3 tax payments a year, Hong Kong has 4, but Romania has 89 and the Ukraine 98. Some of the higher number of payments is related to the greater number of "other taxes" and the absence of electronic payments.

When it comes to the amount of time TaxpayerCo spends to comply with taxes, the world-wide average is 406 hours per year, but it varies from 229 hours for rich countries to 640 hours for lower middle income countries (and 425 hours for poor countries). TaxpayerCo in Singapore would spend 30 hours a year complying with taxes; TaxpayerCo in Switzerland would spend 63. The corresponding numbers are 2185 hours in the Ukraine and 2600 hours in Brazil. Part of the burden of taxation in poorer countries clearly comes from administration, and not just rates ${ }^{17}$.

Over 2003-2005, the world-wide average investment to GDP ratio is about 21\%, and is not substantially different across income groups. There is significant variation across countries: investment to GDP ratio is above $30 \%$ in Jamaica, Mongolia, Vietnam, and of course China (40.8\%). In contrast, investment to GDP ratio is the lowest, at below 15\%, in Uruguay, Bolivia, Malawi, and the Kyrgyz Republic. Relatively little of that

\footnotetext{
${ }^{17}$ The high correlation of our measures of tax compliance with per capita income and legal origins (see below) raises the concern that these measures reflect the quality of government more broadly rather than merely the costs of tax compliance (see La Porta et al. 1999).
} 
investment is FDI, although several authors consider FDI numbers to be more accurate than overall investment numbers. The World Bank ratio of Foreign Direct Investment to GDP averages to 3.36\% between 2003 and 2005, and appears to be somewhat higher for the middle income than for the rich and the poor countries. Ireland, Denmark, and Bolivia have the lowest FDI numbers, Lebanon, Singapore, and Hong Kong the highest.

Business density relative to working-age population is a somewhat unusual measure of entrepreneurship, but might be a reasonable one. The variable plausibly declines from 7.63 incorporated businesses per 100 workers for high income countries to 1.08 for low income countries, which might reflect both fewer businesses at lower levels of development, and presumably fewer official businesses. The data point to .004 businesses per 100 workers in Burkina Faso, .04 in Senegal, but rising all the way to 15 in Malaysia and 16 in Sweden. The rise of business density with income is statistically significant. This measure of entrepreneurship is available for 80 countries.

Entry is defined as the number of newly registered limited liability corporations, as a percentage of the stock of such firms, for 62 countries (averaged over 2000-2004). The world-wide average entry rate is about $8.1 \%$, and tends to be somewhat higher for the rich and upper middle income countries (8.8\% and 9.1\%, respectively) than for the lower middle income and poor countries (7.3\% and 6.4\%, respectively). The difference in entry rates between the high and the low income countries is statistically significant. The entry rates are as low as 2\% in the Philippines, 3\% in Peru, Sri Lanka, and Japan, and as high as $15 \%$ in Kazakhstan and 16\% in New Zealand.

In addition to the aggregate measures of investment and entrepreneurship, we also consider resource allocation within and between sectors, although in smaller samples. 
For both manufacturing and services, median investment to sales ratios in the Enterprise Survey sample are around 1\%, much lower than the aggregate Investment to GDP ratios. As we indicated, this is in part because we have sufficient data only to estimate investment in new machinery, in part because public investment is excluded, and in part because Enterprise Surveys may exclude the largest firms. Informal economies are huge, reaching around 35 percent in lower middle and low income countries. Finally, ratios of debt to equity are much higher in the richer than in the poorer countries.

Table 4 presents the same variables as Table 3, except it organizes them by legal origin of national commercial laws rather than per capita income. In earlier work, legal origin has been found to be a strong predictor of national regulatory strategies, with civil law (particularly French civil law) countries providing less market-friendly regulation than common law countries (see LaPorta et al. 2008 for an overview). Here we check whether our variables vary significantly by legal origin.

There is no evidence that statutory corporate tax rates vary by legal origin, although there is some evidence that German legal origin countries (several of which are in East Asia and Eastern Europe) have lower $1^{\text {st }}$ year effective rates. There is also weak evidence that, for the 5-year effective corporate tax rates, common law countries have 3\% higher rates, on average, than French civil law countries. The labor tax is higher in civil law countries, although this might merely reflect the fact that these countries impose labor taxes on firms rather than individuals. French legal origin countries also have higher levels of "other taxes," although the difference is not statistically significant. Civil law countries also have a higher rate of VAT and sales taxes than common law countries do. Highest bracket personal income tax rates do not vary much by legal origin. 
For tax administration, French legal origin countries exhibit sharply higher numbers of tax payments and time to comply with taxes than other legal traditions (particularly common law). This result is consistent with the finding of higher formalism and burden of government regulation in the French legal origin countries (Djankov et al. 2002, 2003, La Porta et al. 2008). There is not much difference in overall investment, FDI, or entrepreneurship rates among legal origins. Finally, there is some evidence that French civil law countries have larger informal economies than do common law ones.

\section{Results}

We first show the basic relations between corporate taxes and investment and entrepreneurship, then check their robustness to controls and alternative specifications.

\section{Basic Results}

Table 5 presents our main findings; Figures 1-4 illustrate them. We use the four measures of investment and entrepreneurship as dependent variables, and the three corporate tax rates as independent variables, for a total of 12 specifications. In Table 5, we use no controls. The results for the statutory tax rate are similar to those for effective rates in both the magnitude and the statistical significance (except for aggregate investment). Also, the results for the $1^{\text {st }}$ year and 5-year effective corporate income tax rates are very similar (the two rates are correlated at .92). As we indicated in the introduction, we do not believe that, given our data, we can distinguish the relative importance of marginal and effective tax rates. For these reasons, we focus the results using the $1^{\text {st }}$ year effective tax rate even though the statutory rate is often significant. 
The results show no statistically significant effect of the statutory tax rate on investment but a large effect of that rate on FDI. The effects of effective rates on both investment and FDI are statistically significant and large. The estimates indicate that raising the $1^{\text {st }}$ year effective tax rate by 10 percentage points reduces the investment rate by 2.2 percentage points (average investment rate is 21.5\%) and FDI rate by 2.3 percentage points (average FDI rate is $3.36 \%)^{18}$. We have confirmed these FDI results using data from the OECD (see Appendix D). We also collected information from the Bureau of Economic Analysis on US direct investment in foreign countries. Our results on the relationship between taxes and investment are not statistically significant for these US numbers. However, the US FDI represents only 3\% of the world's total.

The effects of taxes on entrepreneurship are large and statistically significant, and show up with both the statutory and the effective tax rates. A 10 percentage point increase in the $1^{\text {st }}$ year effective corporate tax rate reduces business density by 1.9 firms per 100 people (average is 5), and the average entry rate by 1.4 percentage points (average is 8$)^{19}$.

Before checking the robustness of these findings, we report the results of running these specifications with Hassett-Mathur (2006) data. The overlap of the two samples is 64 observations. The correlation of our $1^{\text {st }}$ year effective tax rate with their Effective Average Tax Rate (EATR) is .56, and with their Effective Marginal Tax Rate (EMTR) is .48. Both correlations are highly statistically significant. Neither of the two Hassett-

\footnotetext{
${ }^{18}$ Our estimates are larger, but in the same ballpark, than those of Desai, Foley, and Hines (2004b), who use a different methodology. We also examined the effects of taxation on the aggregate capital labor ratio, updating Caselli and Feyrer (2007) to 2003 and 2004. We did not find any significant results. We attempted to build up new estimates of the capital labor ratio from the World Bank's Enterprise Survey, but the Survey is much less suited for this than for constructing the investment measure.

${ }^{19}$ Some studies examine the effect of personal income taxes on entrepreneurial activity in the United States, and find significant effects. See, e.g., Gentry and Hubbard (2000) and Cullen and Gordon (2007).
} 
Mathur rates significantly predicts aggregate investment. EMTR predicts FDI at the $10 \%$ significance level, and the coefficient is roughly half of that on our $1^{\text {st }}$ year effective tax rate. The EATR (but not EMTR) is also a statistically significant predictor of the two entrepreneurship variables, with coefficients roughly two thirds of ours. Hassett-Mathur variables thus point in the same direction as ours, but not as strongly.

\section{Robustness}

The magnitude of the effects documented in Table 5 is large, and raises obvious questions about spuriousness. In this subsection, we add one at a time a variety of variables to the specifications in Table 5 to verify whether the results are robust ${ }^{20}$.

First, we add other tax variables. Labor taxes do not enter statistically significantly, and do not affect the coefficients on corporate tax variables (results not presented). As Table 5a shows, "other taxes" have large adverse effects on investment and business density, especially in specifications with the statutory corporate tax rate. The addition of these tax rates to the regressions marginally reduces but far from eliminates the adverse effects of corporate income tax. One possible reason that "other taxes" matter so much is that the countries that have trouble collecting ordinary taxes, perhaps for reasons of administrative failure, impose them at higher rates.

Table $5 \mathrm{~b}$ adds VAT and sales tax to the regressions. The effect is negative but relatively small, and only significant for the FDI regressions. Table 5c adds the highest national rate of personal income tax. The variable does not have much of an effect on corporate income tax coefficients. Personal income tax does not enter significantly into the entrepreneurship regressions, enters negatively and significantly the FDI regressions

\footnotetext{
${ }^{20}$ One observation that looks very influential in Figures 1-4 is Bolivia. The results are robust to omitting it.
} 
(although with small coefficients), and surprisingly enters positively and significantly for aggregate investment. The last result is a fluke caused by China and Vietnam, which have both very high personal tax rates and investment rates. Without them, there is no relationship. Overall, our main findings on corporate income taxes are robust to the inclusion of any of the additional tax rates we have considered.

When we add the logarithm of time to comply with taxes, it only adversely affects business density (not presented). This result does not survive the additional inclusion of per capita income (both business density and time to comply with taxes are highly correlated with the level of development). The logarithm of the number of tax payments in Table 5d has no effect on investment and FDI, but it does negatively affect both business density and entry (and the entry result survives the inclusion of per capita income). These findings show that administrative burdens, or perhaps the low quality of government more generally, deter formal entrepreneurship. The coefficients on corporate income tax variables are not significantly affected by these additional controls.

Investment and entrepreneurship might be affected by the quality of tax enforcement or, conversely, tax evasion. The Global Competitiveness Report presents a measure of Tax Evasion for 64 of the countries in our sample, with higher scores corresponding to less evasion. As Table 5e shows, this measure is uncorrelated with aggregate investment, but is a strong positive predictor of FDI, business density, and the entry rate. Better tax enforcement is thus associated with more investment and entrepreneurship, although it is hard to say whether this survey measure captures tax enforcement per se or better institutions generally. Importantly, the coefficients on our tax variables fall only by a quarter, and remain statistically significant. 
Next, we control for institutions more generally. We do this in three ways: lagged per capita income, which might also capture other sources of heterogeneity, security of property rights, and regulation. Table $5 \mathrm{f}$ presents the results of including the log of 2003 per capita income, which has no effect on investment or FDI, but does have a large and positive effect on entrepreneurship. It does not, however, materially affect the coefficients on corporate tax rates. Table $5 g$ alternatively controls for the IEF Property Rights Index. Greater perceived security of property rights has a positive effect on our two measures of entrepreneurship, but none on our two measures of investment. The coefficients on corporate tax rates do not change much. Several other perception-based measures of the quality of the legal system and property right protection yield similar results. Controlling for property rights does not change our findings on corporate taxes.

In Table 5h, we control for the number of procedures it takes to start a business from the Doing Business update of Djankov et al. (2002). The impact of the $1^{\text {st }}$ year effective corporate tax rate on investment and entrepreneurship is not materially affected by this control. Entry regulation does not affect investment, but has a significant adverse effect on the entry rate and business density. An extra procedure reduces the entry rate by roughly .32 percentage points, so going from barely regulated to most regulated countries would reduce the entry rate by as much as 5 percentage points per year.

In Table 5i, we control for a measure of another regulation that might deter investment and entrepreneurship, namely the employment rigidity index from the Doing Business update of Botero et al. (2004). Including the index has a minor influence on the magnitude of tax effects. At the same time, employment regulation adversely affects FDI and to a lesser extent business density and entry. 
Another potentially important omitted variable is inflation. Inflation may have an adverse effect on investment, in part because depreciation deductions are not indexed in most countries (e.g., Auerbach and Jorgenson 1980, Summers 1981). Moreover, countries that have difficulty collecting taxes might finance their budgets, including capital budgets, by printing money. In Table $5 j$ we add the average 1995-2004 inflation as a control. This long run measure of inflation has a mildly significant adverse effect on investment and business density, and none on FDI or entry. The inflation variable does not materially affect the coefficients on the measures of corporate income tax. In Table 5k, we try 2004 seignorage as a measure of government reliance on the printing press. Seignorage has a huge positive effect on investment, probably because of the direct effect of printing money on government capital expenditures. Seignorage has no effect on FDI and large negative and statistically significant effects on the entrepreneurship variables. The inclusion of seignorage does not impact the tax coefficients, however.

As an additional check, we have computed the 5-year effective corporate tax rate allowing TaxpayerCo's revenues and costs, but not depreciation deductions, to rise with inflation (regardless of whether the law allows for indexation of depreciation deductions). This inflation-adjusted 5-year effective corporate tax rate was correlated with the not inflation-adjusted one at $99 \%$. The results using this rate were virtually identical, and so are not reported. In this time of low world-wide inflation and this cross-country context, then, we do not find evidence that inflation has much influence on investment.

One might also argue that investment and entrepreneurship are influenced by a country's openness to trade. In Table 5l, we include the Economic Freedom of the World freedom to trade internationally index in the regressions. The index does not matter for 
investment, but has a positive effect on FDI, business density, and entry. The inclusion of the index does not materially affect the large adverse effects of corporate taxes on FDI and entry, although it does eliminate the significance of the effect on business density.

So what is the bottom line of these robustness checks? Our empirical design can never entirely eliminate the concern that some other factor correlated with the corporate tax rate influences investment. However, having tried a range of possible theories, we have not found what that factor might be. While several of the many factors we consider affect investment and/or entrepreneurship, none substantially diminishes the influence of the effective corporate tax rate. According to the evidence we have presented, corporate taxes have a substantial adverse effect on investment and entrepreneurship.

\section{Allocation}

In Table 6, we look at the influence of corporate taxes on different sectors, using the World Bank Enterprise Survey's estimates of new machinery investment in manufacturing and services. The samples now are much smaller, especially for services. The results show that $1^{\text {st }}$ and 5-year Effective Tax Rates have an adverse effect on investment in manufacturing but not in services. Even with a very small sample, the coefficients for manufacturing are roughly half of what we obtained with aggregate data. This evidence is consistent with Davis and Henrekson (2004), who suggest that the relevant margin of distortion for services might be informality rather than reduction in formal investment. Alternatively, we might just have bad data for investment in services.

In the same spirit, we look at the effect of corporate taxes on the size of the informal economy, since one of the principal ways in which taxes might deter official 
entry or official investment is by keeping firms in the informal sector. A 10 percentage point increase in the $1^{\text {st }}$ year effective tax rate raises the informal economy as a share of economic activity by nearly 2 percentage points. This result is robust to the inclusion of the Global Competitiveness Report measure of tax evasion, suggesting that the tax rates, rather than tax administration more generally, influence informality ${ }^{21}$. Consistent with Johnson, Kaufmann, and Shleifer (1997), Davis and Henrekson (2004), Schneider (2005), and La Porta and Shleifer (2008), taxes are an important reason firms stay unofficial.

These results have important implications for our findings on the large adverse effects of corporate income taxation on investment and entrepreneurship. The measures of investment, FDI, business density, and entry we use all reflect formal economic activity. Corporate taxes might affect these measures either by reducing total activity or by keeping it informal. The finding on the informal economy suggests that at least part of the adverse effect of taxes is to keep economic activity, such as investment and new business formation, informal, rather than to eliminate activity altogether.

The impact of corporate taxes is not just that on informality, however. Corporate taxes have a large adverse effect on FDI, virtually all of which is formal. Also relevant is the adverse effect on manufacturing investment in the Enterprise Survey, which deals only with formal firms. It seems likely, then, that corporate income taxation diminishes aggregate investment and entrepreneurship, and not only influences formality.

In Table 7, we ask whether corporate taxes encourage debt finance, since interest payments are universally tax-deductible. We control for the logarithm of 2003 GDP per

\footnotetext{
${ }^{21}$ The picture with other controls is more mixed. The coefficient on the $1^{\text {st }}$ Year Effective Tax rate remains significant if we control for the VAT and sales tax, the top marginal tax rate, the property rights index, employment rigidity, and inflation. It loses significance (without falling much in magnitude) if we control for the number of tax payments, the number of procedures to start a business, seignorage, and freedom to trade internationally.
} 
capita, as well as the ratio of equity market capitalization to GDP. The control variables suggest that firms in richer countries have higher debt to equity ratios, but that the size of the equity market does not matter. Taxes, however, do. A 10 percentage point increase in the $1^{\text {st }}$ year effective corporate tax rate raises the debt to equity ratio by highly statistically significant 40 percentage points (the mean is $111 \%$ ). In our data, countries with higher effective (as well as statutory) tax rates use sharply more debt. This result is consistent with most theories of optimal capital structure (Graham 2003).

\section{Conclusion}

This paper presents basic statistical relationships between corporate taxes, investment, and entrepreneurship using new data on effective $1^{\text {st }}$ year and 5-year corporate income tax rates for 85 countries. We present cross-country evidence that effective corporate tax rates have a large and significant adverse effect on corporate investment and entrepreneurship. This effect is robust if we control for other tax rates, including personal income taxes and the VAT and sales tax, for measures of administrative burdens, tax compliance, property rights protection, regulations, economic development, openness to foreign trade, seignorage, and inflation. Higher effective corporate income taxes are also associated with lower investment in manufacturing but not in services, a larger unofficial economy, and greater reliance on debt as opposed to equity finance. In these new data, corporate taxes matter a lot, and in ways consistent with basic economic theory. 


\section{References}

Alesina, Alberto, Silvia Ardagna, Giuseppe Nicoletti, and Fabio Schiantarelli. 2005.

"Regulation and Investment," Journal of the European Economic Association, 3(4): 791-825.

Auerbach, Alan. 1979. "Wealth Maximization and the Cost of Capital,” Quarterly Journal of Economics 93(3): 433-446.

Auerbach, Alan. 1983. “Corporate Taxation in the United States,” Brookings Papers on Economic Activity 1983(2): 451-513.

Auerbach, Alan. 2002. “Taxation and Corporate Financial Policy,” in Alan Auerbach and Martin Feldstein (eds.) Handbook of Public Economics, Vol. III, 1251-1292, Amsterdam: North-Holland.

Auerbach, Alan, and Kevin Hassett. 1992. “Tax Policy and Business Fixed Investment in the United States.” Journal of Public Economics 47(2): 141-170.

Auerbach, Alan, and Dale Jorgenson. 1980. "Inflation-Proof Depreciation of Assets," Harvard Business Review, September/October: 113-118.

Barro, Robert. 1991. “Economic Growth in a Cross Section of Countries,” Quarterly Journal of Economics 106(2): 407-443.

Baumol, William, Robert Litan, and Carl Schramm. 2007. Good Capitalism, Bad Capitalism, and the Economics of Growth and Prosperity. New Haven, CT: Yale University Press.

Botero, Juan, Simeon Djankov, Rafael La Porta, Florencio Lopez-de-Silanes, and Andrei Shleifer. 2004. “The Regulation of Labor,” Quarterly Journal of Economics 119(4): 1339-1382.

Caselli, Francesco, and James Feyrer. 2007. “The Marginal Product of Capital,” Quarterly Journal of Economics 122(2): 535-568.

Ciccone, Antonio, and Elias Papaioannou. 2006. “Red tape and delayed entry.” C.E.P.R. Discussion Paper 5996.

Cullen, Julie Berry, and Roger Gordon. 2007. "Taxes and Entrepreneurial Risk-Taking: Theory and Evidence in the U.S.,” Journal of Public Economics 91(7-8): 14791505.

Cummins, Jason, Kevin Hassett, and Glenn Hubbard. 1996. "Tax Reforms and Investment: A Cross-Country Comparison,” Journal of Public Economics 62 (12): 237-273. 
Davis, Steven, and Magnus Henrekson. 2004. "Tax Effects on Work Activity, Industry Mix, and Shadow Economy Size: Evidence from Rich-Country Comparisons,” Cambridge, MA: National Bureau of Economic Research Working Paper 10509.

DeLong, Bradford, and Lawrence Summers. 1991. "Equipment Investment and Economic Growth,” Quarterly Journal of Economics 106(2): 445-502.

Desai, Mihir, Fritz Foley, and James Hines. 2004a. "A Multinational Perspective on Capital Structure Choice and Internal Capital Markets,” Journal of Finance 59(6): 2451-2487.

Desai, Mihir, Fritz Foley, and James Hines. 2004b. "Foreign Direct Investment in a World of Multiple Taxes,” Journal of Public Economics 88(12): 2727-2744.

Devereux, Michael, and Rachel Griffith. 2003. "Evaluating Tax Policy for Location Decisions,” International Tax and Public Finance 10, 107-126.

Devereux, Michael, Rachel Griffith, and Alexander Klemm. 2002. "Corporate Income Tax Reforms and International Tax Competition,” Economic Policy 17(35): 449495.

Djankov, Simeon, Rafael La Porta, Florencio Lopez-de-Silanes, and Andrei Shleifer. 2002. “The Regulation of Entry,” Quarterly Journal of Economics 117(1): 1-37.

Djankov, Simeon, Rafael La Porta, Florencio Lopez-de-Silanes, and Andrei Shleifer. 2003. “Courts,” Quarterly Journal of Economics 118(2): 453-517.

Feldstein, Martin, Louis Dicks-Mireaux, and James Poterba. 1983. "The Effective Tax Rate and the Pretax Rate of Return,” Journal of Public Economics 21(2): 129158.

Gentry, William, and Glenn Hubbard. 2000. "Tax Policy and Entrepreneurial Entry," American Economic Review 90(2): 283-287.

Goolsbee, Austan. 1998. "Taxes, Organizational Form, and the Deadweight Loss of the Corporate Income Tax,” Journal of Public Economics 69(1): 143-152.

Gordon, Roger, and James Hines. 2002. "International Taxation," in Alan Auerbach and Martin Feldstein (eds.), Handbook of Public Economics, Vol. IV, 1935-1995, Amsterdam: North-Holland.

Graham, John. 1996. "Debt and the Marginal Tax Rate,” Journal of Financial Economics 41(1): 41-73.

Graham, John. 2003. “Taxes and Corporate Finance: A Review.” Review of Financial Studies 16 (4): 1075-1129. 
Gwartney, James, Robert Lawson, and William Easterly. 2006. Economic Freedom of the World 2006 Annual Report. Vancouver, CA: The Fraser Institute.

Hall, Robert, and Dale Jorgenson. 1967. "Tax Policy and Investment Behavior," American Economic Review 57 (3): 391-414.

Haltiwanger, John, Stefano Scarpetta, and Helena Schweiger. 2006. "Assessing Job Flows Across Countries: The Role of Industry, Firm Size, and Regulations,” The World Bank Policy Research Working Paper 4070, Washington: World Bank.

Hassett, Kevin, and Glenn Hubbard. 2002. “Tax Policy and Business Investment,” In Alan Auerbach and Martin Feldstein (eds.), Handbook of Public Economics, Vol. III, 1293-1343. Amsterdam: North-Holland.

Hassett, Kevin, and Aparna Mathur. 2006. “Taxes and Wages,” American Enterprise Institute Working Paper \#128.

Heritage Foundation. 2004. 2004 Index of Economic Freedom, Washington, D.C.: Heritage Foundation and The Wall Street Journal.

Hines, James. 2005. “Corporate Taxation and International Competition,” Mimeo.

Hines, James, and Eric Rice. 1994. "Fiscal Paradise: Foreign Tax Havens and American Business,” Quarterly Journal of Economics 109(1): 149-182.

Johnson, Simon, Daniel Kaufmann, and Andrei Shleifer. 1997. "The Unofficial Economy in Transition,” Brookings Papers on Economic Activity 1997(2): 159-239.

Jorgenson, Dale. 1963. “Capital Theory and Investment Behavior,” American Economic Review 53, 247-259.

King, Mervyn, and Don Fullerton, eds. 1984. The Taxation of Income from Capital, Chicago: University of Chicago Press for the NBER.

Klapper, Leora, Luc Laeven, and Raghuram Rajan. 2006. "Entry Regulation as a Barrier to Entrepreneurship,” Journal of Financial Economics 82(3): 591-629.

La Porta, Rafael, Florencio Lopez-de-Silanes, Andrei Shleifer, and Robert Vishny. 1997. “Legal Determinants of External Finance,” Journal of Finance 52(3): 1131-1150.

La Porta, Rafel, Florencio Lopez-de-Silanes, Andrei Shleifer, and Robert Vishny. 1999. "The Quality of Government," Journal of Law, Economics, and Organization 15(1): 222-279. 
La Porta, Rafael, Florencio Lopez-de-Silanes, and Andrei Shleifer. 2008. "Economic Consequences of Legal Origins,” Journal of Economic Literature 46(2): 285-332.

La Porta, Rafael, and Andrei Shleifer. 2008. "The Unofficial Economy and Economic Development," Brookings Papers on Economic Activity 2, forthcoming.

Mackie-Mason, Jeffrey, 1990. “Do Taxes Affect Corporate Financing Decisions?” Journal of Finance 45 (5): 1471-1493.

Miller, Merton. 1977. “Debt and Taxes,” Journal of Finance 32 (2): 261-275.

Miller, Merton, and Franco Modigliani. 1958. "The Cost of Capital, Corporation Finance and the Theory of Investment," American Economic Review 48(3): 261-297.

Schneider, Friedrich. 2005. "Shadow Economies around the World: What Do We Really Know?” European Journal of Political Economy 21(3): 598-642.

Slemrod, Joel. 1990. "Tax Effects on Foreign Direct Investment in the United States: Evidence from a Cross-Country Comparison,” in Assaf Razin and Joel Slemrod (eds.) Taxation in the Global Economy. Chicago: University of Chicago Press, 79117.

Summers, Lawrence. 1981. "Taxation and Corporate Investment: A q-Theory Approach,” Brookings Papers on Economic Activity, 1981(1): 67-127.

World Economic Forum. 2005. The Global Competitiveness Report 2005-2006. Geneva: Palgrave Macmillan.

World Economic Forum. 2006. The Global Competitiveness Report 2006-2007. Geneva: Palgrave Macmillan. 
Table 1. Pre-tax financial statements

\section{A - Information provided in the balance sheet}

Assets
\begin{tabular}{|l|c|r|}
\hline \multicolumn{1}{|c|}{ Category } & Multiplication Factor & Values for the U.S. \\
\hline Net Cash & 20 & 755,600 \\
\hline Inventory & 35 & $1,322,300$ \\
\hline Accounts Receivable & 50 & $1,889,000$ \\
\hline Land & 30 & $1,133,400$ \\
\hline Building & 40 & $1,511,200$ \\
\hline Machinery & 60 & $2,266,800$ \\
\hline Truck & 5 & 188,900 \\
\hline Computers & 5 & 188,900 \\
\hline Office Equipment & 5 & 188,900 \\
\hline Total Assets & $\mathbf{2 5 0}$ & $\mathbf{9 , 4 4 5 , 0 0 0}$ \\
\hline
\end{tabular}

\section{Liabilities}

\begin{tabular}{|l|c|r|}
\hline \multicolumn{1}{|c|}{ Category } & Multiplication Factor & Values for the U.S. \\
\hline Short Term Debt & 55 & $2,077,900$ \\
\hline Accounts Payable - Trade & 50 & $1,889,000$ \\
\hline Long Term Debt & 43 & $1,624,540$ \\
\hline
\end{tabular}

Equity

\begin{tabular}{|l|c|r|}
\hline \multicolumn{1}{|c|}{ Category } & Multiplication Factor & Values for the U.S. \\
\hline Paid-in Capital & 102 & $3,853,560$ \\
\hline Total Liabilities and Equity & $\mathbf{2 5 0}$ & $\mathbf{9 , 4 4 5 , 0 0 0}$ \\
\hline
\end{tabular}

\section{B - Information provided in the profit and loss statement}

\begin{tabular}{|l|c|r|}
\hline \multicolumn{1}{|c|}{ Category Multiplication } & Factor & Values for the U.S. \\
\hline Sales & 1050 & $39,699,000$ \\
\hline Cost of Goods Sold & 875 & $33,057,500$ \\
\hline Managers & $9(=2.25$ per manager * 4$)$ & 340,020 \\
\hline Assistants & $10\left(=1.25\right.$ per assistant $\left.{ }^{*} 8\right)$ & 377,800 \\
\hline Workers & $48\left(=1.00\right.$ per worker $\left.{ }^{*} 48\right)$ & $1,813,440$ \\
\hline Administrative expenses & 10 & 377,800 \\
\hline Advertising Expenses & 10.5 & 396,690 \\
\hline Machinery Repair Expenses & 3 & 113,340 \\
\hline Interest Expense & 5.5 & 207,790 \\
\hline
\end{tabular}


Table 2. Variable Definitions

\begin{tabular}{|c|c|c|}
\hline Variable name & Source & Definition \\
\hline \multicolumn{3}{|l|}{ Tax Variables } \\
\hline Statutory Corporate Tax Rate (\%) & Authors' calculations & $\begin{array}{l}\text { The tax rate for the highest bracket of all taxes on corporate income. We take } \\
\text { into account the deductibility of any of these taxes from the tax based used for } \\
\text { calculating pre-tax corporate income. }\end{array}$ \\
\hline 1st Year Effective Tax Rate (\%) & Authors' calculations & $\begin{array}{l}\text { The tax rate obtained by dividing the total corporate tax TaxpayerCo pays by it } \\
\text { pretax earnings. }\end{array}$ \\
\hline 5-year Effective Tax Rate (\%) & Authors' calculations & $\begin{array}{l}\text { The tax rate obtained by dividing the present-discounted value of the total } \\
\text { corporate tax TaxpayerCo pays over five years by the present-discounted value } \\
\text { of the pretax earnings in these five years. }\end{array}$ \\
\hline Labor Tax (\%) & Authors' calculations & $\begin{array}{l}\text { The sum of all labor-related taxes payable by TaxpayerCo, including payroll } \\
\text { taxes, mandatory social security contributions, mandatory health insurance, } \\
\text { mandatory unemployment insurance, worker's compensation insurance } \\
\text { contributions, and any local contributions that are proportional to payroll or } \\
\text { number of employees. It is expressed as a percentage of pretax earnings. }\end{array}$ \\
\hline Other taxes (\%) & Authors' calculations & $\begin{array}{l}\text { The sum of all taxes payable TaxpayerCo other than corporate income taxes } \\
\text { and labor taxes where the statutory incidence is on the firm. It is the sum of all } \\
\text { property tax, business license tax, financial transactions tax, turnover tax, and } \\
\text { asett and capital tax payable by TaxpayerCo. It is expressed as a percentage } \\
\text { pretax earnings. }\end{array}$ \\
\hline VAT and Sales tax & Authors' calculations & $\begin{array}{l}\text { The sum of all consumption tax rates payable or collected by TaxpayerCo, } \\
\text { including value added tax rate, sales tax rate, and turnover tax rate, and and } \\
\text { related surtaxes. }\end{array}$ \\
\hline PIT top marginal rate & $\begin{array}{l}\text { World Bank (World Development } \\
\text { Indicators), PricewaterhouseCoopers, and } \\
\text { IBFD }\end{array}$ & $\begin{array}{l}\text { The tax rate for the highest bracket of tax on personal income. Only taxes at th } \\
\text { national level are included. }\end{array}$ \\
\hline Number of tax payments & World Bank (Doing Business data) & $\begin{array}{l}\text { The tax payments indicator reflects the total number of taxes paid, the method } \\
\text { of payment, the frequency of payment, and the number of agencies involved for } \\
\text { this standardized case during the second year of operation. It includes } \\
\text { payments made by the company on consumption taxes, such as sales tax or } \\
\text { value added tax. }\end{array}$ \\
\hline Time to comply with taxes (in hours) & World Bank (Doing Business data) & $\begin{array}{l}\text { Time is recorded in hours per year. The indicator measures the time to prepare } \\
\text { file and pay (or withhold) three major types of taxes: the corporate income tax, } \\
\text { value added or sales tax, and labor taxes, including payroll taxes and social } \\
\text { security contributions. }\end{array}$ \\
\hline \multicolumn{3}{|l|}{ Outcome variables } \\
\hline Investment $2003-2005$ as $\%$ of GDP & $\begin{array}{l}\text { World Bank (World Development } \\
\text { Indicators) }\end{array}$ & Gross fixed capital formation (formerly gross domestic fixed investment) \\
\hline FDI $2003-2005$ as $\%$ of GDP & $\begin{array}{l}\text { World Bank (World Development } \\
\text { Indicators) }\end{array}$ & $\begin{array}{l}\text { Foreign direct investment is the net inflows of investment to acquire a lasting } \\
\text { management interest ( } 10 \text { percent or more of voting stock) in an enterprise } \\
\text { operating in an economy other than that of the investor. }\end{array}$ \\
\hline FDI $2002-2004$ as $\%$ of GDP & $\begin{array}{l}\text { OECD (International Direct Investment } \\
\text { Statistics) }\end{array}$ & $\begin{array}{l}\text { The Foreign direct investment measured by the OECD is the sum of the direct } \\
\text { investment by all countries made in each OECD member country receiving the } \\
\text { investment (as published in the international direct investment statitics). The } \\
\text { authors then measured this sum as a percentage of the total GDP in the } \\
\text { receiving country. (Total GDP is published by the World Bank (World } \\
\text { Development Indicators).) For each country, these percentages were averaged } \\
\text { over the years } 2002 \text { to } 2004 \text {. }\end{array}$ \\
\hline $\begin{array}{l}\text { Business density per } 100 \text { people } \\
(2003 / 2004)\end{array}$ & $\begin{array}{l}\text { Authors' data, collected from business } \\
\text { registries }\end{array}$ & $\begin{array}{l}\text { The number of limited liability corporations (or their country-specific equivalent } \\
\text { legally registered divided by the working-age population (total population aged } \\
15 \text { to } 64 \text { ). Only businesses with at least one employee that are not } \\
\text { soleproprietorships are included. The variable is scaled to measure the number } \\
\text { of businesses per } 100 \text { people in the working-age population. }\end{array}$ \\
\hline Average entry rate $2000-2004(\%)$ & $\begin{array}{l}\text { Authors' data, collected from business } \\
\text { registries }\end{array}$ & $\begin{array}{l}\text { The average number of limited liability corporations (or their country-specific } \\
\text { equivalent) that were registered per year between } 2000 \text { and } 2004 \text {. Only } \\
\text { businesses with more than one employee that are not soleproprietorships are } \\
\text { included. The variable is scaled to measure the number of businesses per } 100 \\
\text { people in the working-age population. }\end{array}$ \\
\hline $\begin{array}{l}\text { Median manufacturing sector firm } \\
\text { investment }\end{array}$ & World Bank (Enterprise Surveys) & $\begin{array}{l}\text { The country median of the firm level investments in new machinery and } \\
\text { equipment as a percentage of total sales of the firm. }\end{array}$ \\
\hline
\end{tabular}




\section{Table 2. Variable Definitions}

\begin{tabular}{|c|c|c|}
\hline Median service sector firm investmen & World Bank (Enterprise Surveys) & $\begin{array}{l}\text { The country median of the firm level investments in new machinery and } \\
\text { equipment as a percentage of total sales of the firm. }\end{array}$ \\
\hline Size of the informal sector $2005-2007$ & $\begin{array}{l}\text { World Economic Forum (Global } \\
\text { Competitiveness Report 2005-2006 and } \\
\text { 2006-2007) }\end{array}$ & $\begin{array}{l}\text { Average of the size of the informal sector as a percentage of economic activity } \\
\text { in } 2005-2006 \text { and } 2006-2007 \text {. Computed using the scale provided in sections } \\
6.17(2005-2006) \text { and } 6.30(2006-2007) \text {, which report measures on informal } \\
\text { sector activity. }\end{array}$ \\
\hline Debt to equity ratio & $\begin{array}{l}\text { IMF (International Financial Statistics } \\
\text { Database) }\end{array}$ & $\begin{array}{l}\text { Average of the country's companies' debt (book value) as a percentage of } \\
\text { companies' equity (book value) weighted by the companies' market caps. This } \\
\text { ratio is computed using the IMF's Corporate Vulnerability Utility which uses firnt } \\
\text { level data from Datastream and Worldscope. }\end{array}$ \\
\hline \multicolumn{3}{|l|}{ Control variables } \\
\hline Tax evasion & $\begin{array}{l}\text { World Economic Forum (Global } \\
\text { Competitiveness Report 2001/2002) }\end{array}$ & $\begin{array}{l}\text { Executives' assessment of how important tax evasion is in their country (the } \\
\text { lower the measure the more rampant is tax evasion). Based on table } 6.11 .\end{array}$ \\
\hline GDP per capita 2003 & $\begin{array}{l}\text { World Bank (World Development } \\
\text { Indicators) }\end{array}$ & $\begin{array}{l}\text { GDP per cpaita is gross domestic product divided by midyear population. Data } \\
\text { are in constant U.S. dollars. }\end{array}$ \\
\hline IEF Property Rights Index & $\begin{array}{l}\text { The Heritage Foundation (Index of } \\
\text { Economic Freedom) }\end{array}$ & $\begin{array}{l}\text { The property rights index is an assessment of the ability of individuals to } \\
\text { accumulate private property, secured by clear laws that are fully enforced by th } \\
\text { state. }\end{array}$ \\
\hline Procedures to start a business & $\begin{array}{l}\text { World Bank (Doing Business data) } \\
\text { Updates of Djankovet al. (2002) }\end{array}$ & $\begin{array}{l}\text { This variable includes all procedures that are officially required for an } \\
\text { entrepreneur to start up and formally operate an industrial or commercial } \\
\text { business. }\end{array}$ \\
\hline Employment rigidity index & $\begin{array}{l}\text { World Bank (Doing Business data) } \\
\text { Updates of Boteroet al. (2004) }\end{array}$ & $\begin{array}{l}\text { The average of three subindices: a difficulty of hiring index, a rigidity of hours } \\
\text { index, and a difficulty of firing index. }\end{array}$ \\
\hline Average inflation 1995-2004 & $\begin{array}{l}\text { World Bank (World Development } \\
\text { Indicators) }\end{array}$ & $\begin{array}{l}\text { Inflation as measured by the annual growth rate of the GDP implicit deflator } \\
\text { shows the rate of price change in the economy as a whole, averaged over the } \\
\text { period 1995-2004. The GDP implicit deflator is the ratio of GDP in current local } \\
\text { currency to GDP in constant local currency. World Bank national accounts dat } \\
\text { and OECD national accounts data files. }\end{array}$ \\
\hline Seignorage & $\begin{array}{l}\text { IMF (International Financial Statistics } \\
\text { Database) }\end{array}$ & $\begin{array}{l}\text { Currency in circulation outside banks as percentage of total GDP. The data on } \\
\text { currency comes from IFS line } 14 \mathrm{~A} \text {. }\end{array}$ \\
\hline $\begin{array}{l}\text { EFW Freedom to Trade Inter- } \\
\text { nationally Index }\end{array}$ & $\begin{array}{l}\text { The Fraser Institute (Economic Freedom o } \\
\text { the World) }\end{array}$ & $\begin{array}{l}\text { This index measures taxes on international trade, regulatory trade barriers, size } \\
\text { of the trade sector relative to expected, black-market exchange rates, and } \\
\text { international capital market controls. }\end{array}$ \\
\hline \multicolumn{3}{|l|}{ Other variables } \\
\hline Income group & $\begin{array}{l}\text { World Bank (World Development } \\
\text { Indicators) }\end{array}$ & $\begin{array}{l}\text { Economies are divided according to } 2004 \text { GNI per capita, calculated using the } \\
\text { World Bank Atlas method. The groups are: low income, } \$ 905 \text { or less; lower } \\
\text { middle income, } \$ 906 \text { - } \$ 3,595 \text {; upper middle income, } \$ 3,596 \text { - } \$ 11,115 \text {; and } \\
\text { high income, } \$ 11,116 \text { or more. }\end{array}$ \\
\hline Legal origin & La Porta et al. (2008) & $\begin{array}{l}\text { A dummy variable that identifies the legal origin of the Company law or } \\
\text { Commercial Code of each country. The four origins are English, French, } \\
\text { German, and Nordic. }\end{array}$ \\
\hline
\end{tabular}




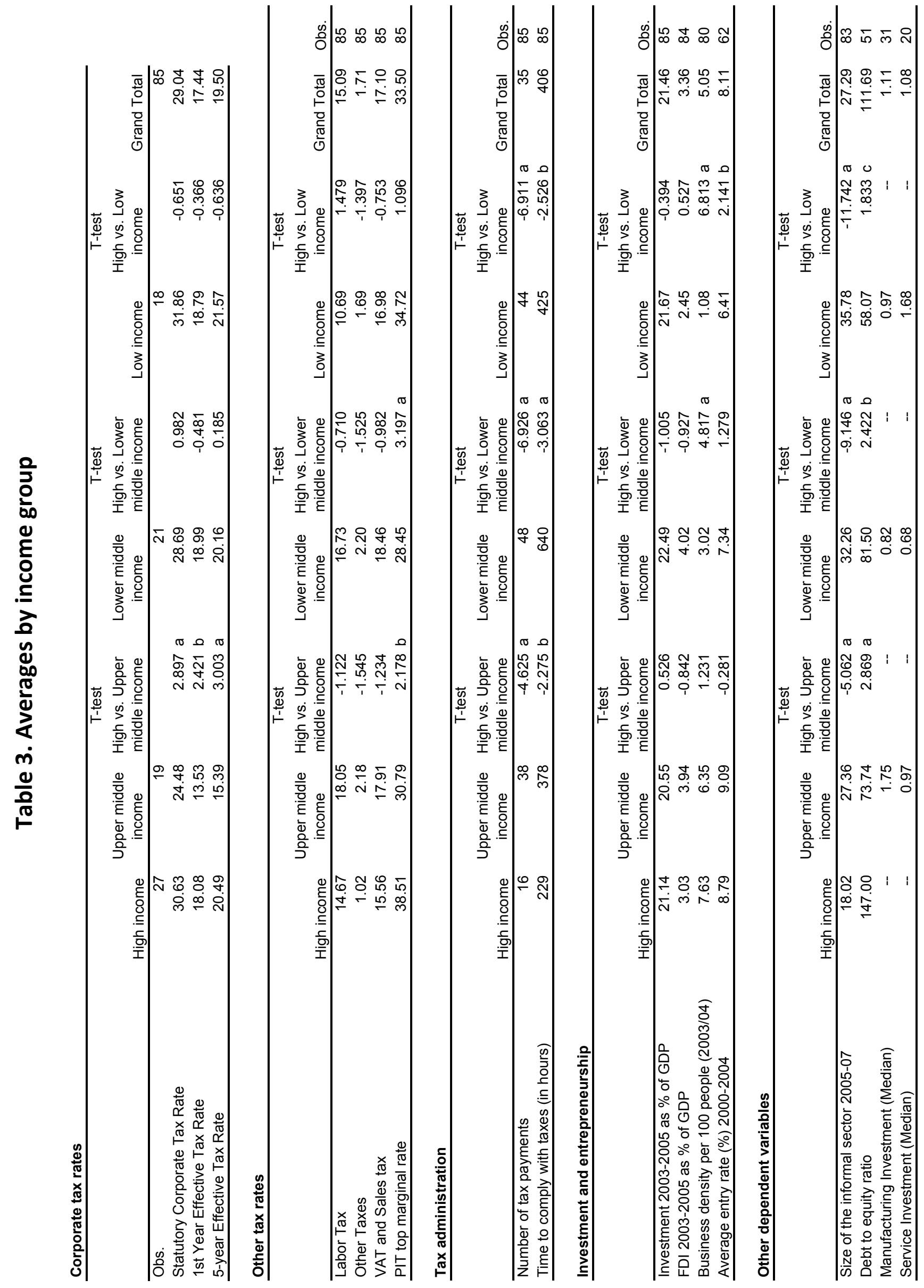



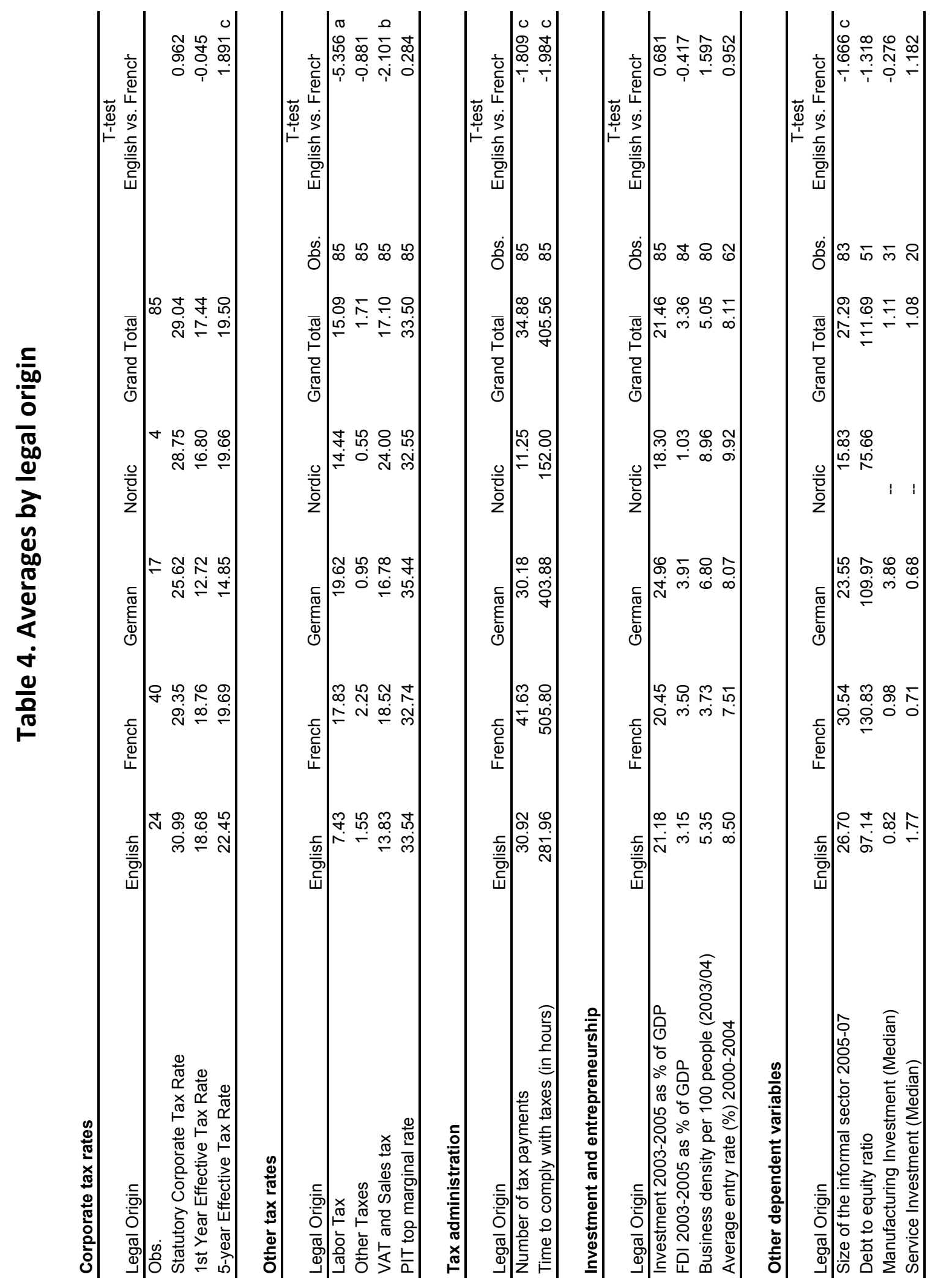
Table 5. Taxes, Investment and Entrepreneurship

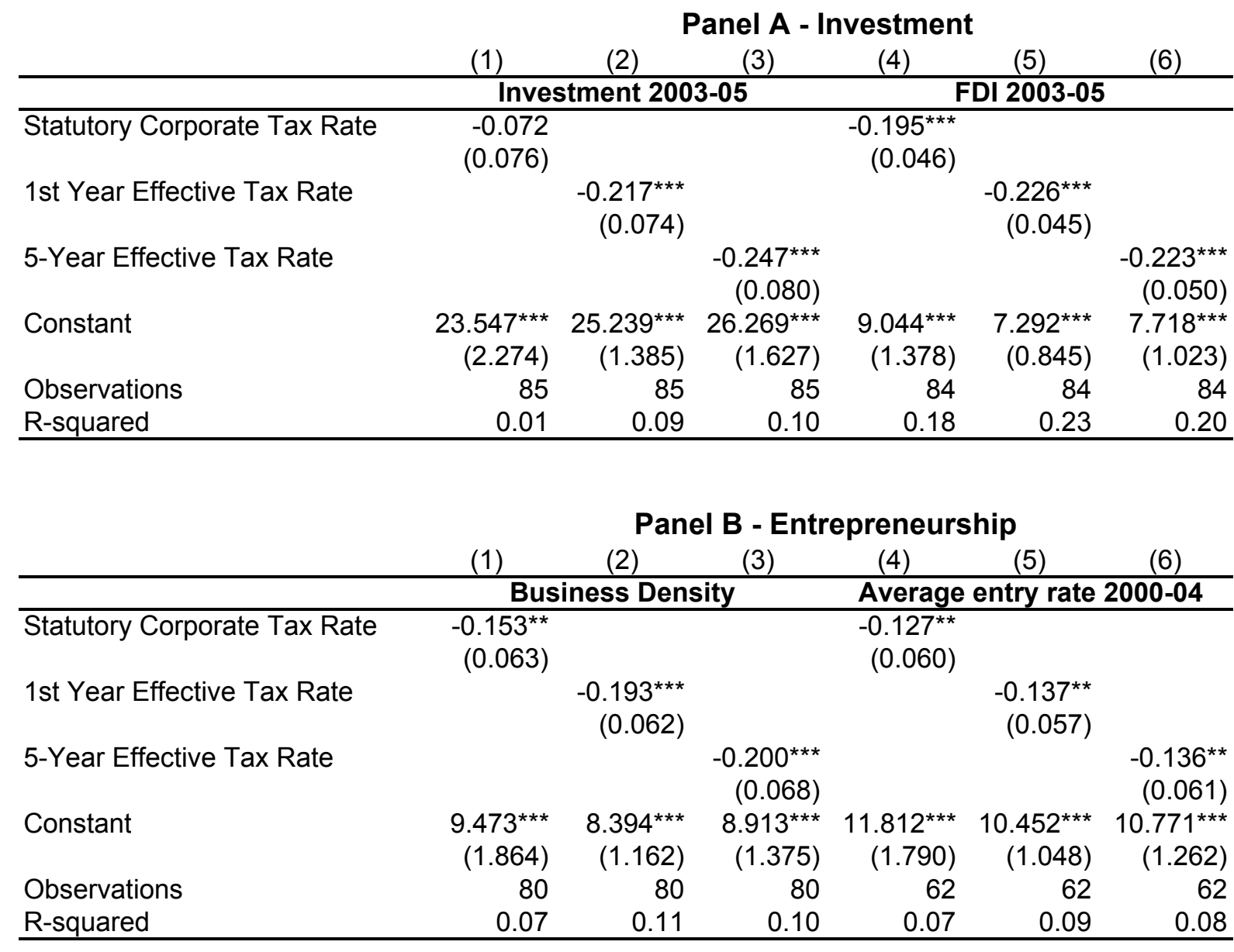

Standard errors in parentheses

${ }^{*}$ significant at $10 \% ;{ }^{* *}$ significant at $5 \%$; ${ }^{* *}$ significant at $1 \%$ 
Table 5a. Other Taxes

\begin{tabular}{|c|c|c|c|c|c|c|}
\hline & \multicolumn{6}{|c|}{ Panel A - Investment } \\
\hline & (1) & (2) & (3) & (4) & (5) & (6) \\
\hline & $\operatorname{lnve}$ & stment 20 & 33-05 & & FDI 2003 & \\
\hline Statutory Corporate Tax Rate & $\begin{array}{l}-0.045 \\
(0.074)\end{array}$ & & & $\begin{array}{l}-0.189^{\star \star \star} \\
(0.047)\end{array}$ & & \\
\hline 1st Year Effective Tax Rate & & $\begin{array}{l}-0.163^{* *} \\
(0.079)\end{array}$ & & & $\begin{array}{l}-0.231^{\text {** }} \\
(0.049)\end{array}$ & \\
\hline 5-Year Effective Tax Rate & & & $\begin{array}{l}-0.192^{* *} \\
(0.084)\end{array}$ & & & $\begin{array}{l}-0.224^{* * *} \\
(0.054)\end{array}$ \\
\hline Other Taxes & $\begin{array}{l}-0.479^{* *} \\
(0.183)\end{array}$ & $\begin{array}{l}-0.346^{*} \\
(0.191)\end{array}$ & $\begin{array}{l}-0.337^{*} \\
(0.189)\end{array}$ & $\begin{array}{l}-0.112 \\
(0.114)\end{array}$ & $\begin{array}{l}0.033 \\
(0.119)\end{array}$ & $\begin{array}{l}0.006 \\
(0.121)\end{array}$ \\
\hline Constant & $\begin{array}{l}23.579^{* * *} \\
(2.197)\end{array}$ & $\begin{array}{l}24.893^{* * *} \\
(1.380)\end{array}$ & $\begin{array}{l}25.778^{* * *} \\
(1.629)\end{array}$ & $\begin{array}{l}9.049^{* * *} \\
(1.378)\end{array}$ & $\begin{array}{l}7.325^{* * *} \\
(0.858)\end{array}$ & $\begin{array}{l}7.727^{* \star *} \\
(1.045)\end{array}$ \\
\hline Observations & 85 & 85 & 85 & 84 & 84 & 84 \\
\hline R-squared & 0.09 & 0.13 & 0.14 & 0.19 & 0.23 & 0.20 \\
\hline
\end{tabular}

\begin{tabular}{|c|c|c|c|c|c|c|}
\hline & (1) & (2) & (3) & (4) & $(5)$ & $(6)$ \\
\hline & \multicolumn{3}{|c|}{ Business Density } & \multicolumn{3}{|c|}{ Average entry rate $2000-04$} \\
\hline Statutory Corporate Tax Rate & $\begin{array}{l}-0.136^{\star \star} \\
(0.062)\end{array}$ & & & $\begin{array}{l}-0.123^{\star \star} \\
(0.060)\end{array}$ & & \\
\hline 1st Year Effective Tax Rate & & $\begin{array}{l}-0.160^{* *} \\
(0.067)\end{array}$ & & & $\begin{array}{l}-0.140^{* *} \\
(0.062)\end{array}$ & \\
\hline 5-Year Effective Tax Rate & & & $\begin{array}{l}-0.164^{* *} \\
(0.072)\end{array}$ & & & $\begin{array}{l}-0.138^{* *} \\
(0.067)\end{array}$ \\
\hline Other Taxes & $\begin{array}{l}-0.313^{* *} \\
(0.155)\end{array}$ & $\begin{array}{l}-0.210 \\
(0.165)\end{array}$ & $\begin{array}{l}-0.224 \\
(0.164)\end{array}$ & $\begin{array}{l}-0.083 \\
(0.136)\end{array}$ & $\begin{array}{l}0.021 \\
(0.146)\end{array}$ & $\begin{array}{l}0.010 \\
(0.147)\end{array}$ \\
\hline Constant & $\begin{array}{l}9.487^{* * *} \\
(1.829)\end{array}$ & $\begin{array}{l}8.178^{* * *} \\
(1.170)\end{array}$ & $\begin{array}{l}8.592^{* * *} \\
(1.388)\end{array}$ & $\begin{array}{l}11.864^{* * *} \\
(1.802)\end{array}$ & $\begin{array}{l}10.474^{* * *} \\
(1.068)\end{array}$ & $\begin{array}{l}10.788^{* * *} \\
(1.296)\end{array}$ \\
\hline Observations & 80 & 80 & 80 & 62 & 62 & 62 \\
\hline R-squared & 0.12 & 0.13 & 0.12 & 0.08 & 0.09 & 0.08 \\
\hline
\end{tabular}

Standard errors in parentheses

${ }^{*}$ significant at $10 \% ;{ }^{* *}$ significant at $5 \% ;{ }^{* * *}$ significant at $1 \%$ 
Table 5b. VAT and Sales Tax

\begin{tabular}{|c|c|c|c|c|c|c|}
\hline & \multicolumn{6}{|c|}{ Panel A - Investment } \\
\hline & (1) & (2) & (3) & (4) & (5) & (6) \\
\hline & $\operatorname{lnve}$ & stment 20 & 33-05 & & FDI 2003- & \\
\hline Statutory Corporate Tax Rate & $\begin{array}{l}-0.071 \\
(0.076)\end{array}$ & & & $\begin{array}{l}-0.196^{\star \star \star} \\
(0.045)\end{array}$ & & \\
\hline 1st Year Effective Tax Rate & & $\begin{array}{l}-0.224^{* * *} \\
(0.074)\end{array}$ & & & $\begin{array}{l}-0.233^{* * *} \\
(0.044)\end{array}$ & \\
\hline 5-Year Effective Tax Rate & & & $\begin{array}{l}-0.271^{\text {*** }} \\
(0.080)\end{array}$ & & & $\begin{array}{l}-0.247^{* * *} \\
(0.049)\end{array}$ \\
\hline VAT and Sales Tax & $\begin{array}{l}-0.074 \\
(0.062)\end{array}$ & $\begin{array}{l}-0.087 \\
(0.060)\end{array}$ & $\begin{array}{l}-0.109^{*} \\
(0.060)\end{array}$ & $\begin{array}{l}-0.069^{*} \\
(0.038)\end{array}$ & $\begin{array}{l}-0.082^{* *} \\
(0.036)\end{array}$ & $\begin{array}{l}-0.101^{* * *} \\
(0.037)\end{array}$ \\
\hline Constant & $\begin{array}{l}24.802^{* * *} \\
(2.500)\end{array}$ & $\begin{array}{l}26.868^{* * *} \\
(1.767)\end{array}$ & $\begin{array}{l}28.612^{* * *} \\
(2.052)\end{array}$ & $\begin{array}{l}10.246^{* * *} \\
(1.508)\end{array}$ & $\begin{array}{l}8.828^{\star \star *} \\
(1.068)\end{array}$ & $\begin{array}{l}9.923^{* * *} \\
(1.272)\end{array}$ \\
\hline Observations & 85 & 85 & 85 & 84 & 84 & 84 \\
\hline R-squared & 0.03 & 0.12 & 0.14 & 0.21 & 0.28 & 0.26 \\
\hline
\end{tabular}

\begin{tabular}{|c|c|c|c|c|c|c|}
\hline & (1) & (2) & (3) & (4) & $(5)$ & $(6)$ \\
\hline & \multicolumn{3}{|c|}{ Business Density } & \multicolumn{3}{|c|}{ Average entry rate $2000-04$} \\
\hline Statutory Corporate Tax Rate & $\begin{array}{l}-0.153^{\star \star} \\
(0.063)\end{array}$ & & & $\begin{array}{l}-0.133^{\star \star} \\
(0.061)\end{array}$ & & \\
\hline 1st Year Effective Tax Rate & & $\begin{array}{l}-0.195^{* * *} \\
(0.063)\end{array}$ & & & $\begin{array}{l}-0.140^{* *} \\
(0.057)\end{array}$ & \\
\hline 5-Year Effective Tax Rate & & & $\begin{array}{l}-0.208^{* * *} \\
(0.069)\end{array}$ & & & $\begin{array}{l}-0.150^{* *} \\
(0.063)\end{array}$ \\
\hline VAT and Sales Tax & $\begin{array}{l}-0.010 \\
(0.051)\end{array}$ & $\begin{array}{l}-0.022 \\
(0.050)\end{array}$ & $\begin{array}{l}-0.037 \\
(0.051)\end{array}$ & $\begin{array}{l}-0.051 \\
(0.072)\end{array}$ & $\begin{array}{l}-0.044 \\
(0.070)\end{array}$ & $\begin{array}{l}-0.068 \\
(0.072)\end{array}$ \\
\hline Constant & $\begin{array}{l}9.640^{* * *} \\
(2.065)\end{array}$ & $\begin{array}{l}8.810^{* * *} \\
(1.501)\end{array}$ & $\begin{array}{l}9.713^{* * *} \\
(1.764)\end{array}$ & $\begin{array}{l}12.859^{* * *} \\
(2.315)\end{array}$ & $\begin{array}{l}11.232^{* * *} \\
(1.643)\end{array}$ & $\begin{array}{l}12.182^{* * *} \\
(1.956)\end{array}$ \\
\hline Observations & 80 & 80 & 80 & 62 & 62 & 62 \\
\hline R-squared & 0.07 & 0.11 & 0.11 & 0.08 & 0.09 & 0.09 \\
\hline
\end{tabular}

Standard errors in parentheses

${ }^{*}$ significant at $10 \% ;{ }^{* *}$ significant at $5 \% ;{ }^{* * *}$ significant at $1 \%$ 
Table 5c. Personal Income Tax Top Marginal Rate

\begin{tabular}{|c|c|c|c|c|c|c|}
\hline & \multicolumn{6}{|c|}{ Panel A - Investment } \\
\hline & $(1)$ & $(2)$ & $(3)$ & $(4)$ & (5) & (6) \\
\hline & \multicolumn{3}{|c|}{ Investment 2003-05 } & \multicolumn{3}{|c|}{ FDI 2003-05 } \\
\hline Statutory Corporate Tax Rate & $\begin{array}{l}-0.119 \\
(0.078)\end{array}$ & & & $\begin{array}{l}-0.175^{\star * *} \\
(0.048)\end{array}$ & & \\
\hline 1st Year Effective Tax Rate & & $\begin{array}{l}-0.235^{\star \star \star} \\
(0.073)\end{array}$ & & & $\begin{array}{l}-0.214^{* * *} \\
(0.044)\end{array}$ & \\
\hline 5-Year Effective Tax Rate & & & $\begin{array}{l}-0.263^{* * *} \\
(0.078)\end{array}$ & & & $\begin{array}{l}-0.213^{\star * *} \\
(0.049)\end{array}$ \\
\hline PIT top marginal rate & $\begin{array}{l}0.102^{* *} \\
(0.047)\end{array}$ & $\begin{array}{l}0.097^{* *} \\
(0.043)\end{array}$ & $\begin{array}{l}0.095^{\star *} \\
(0.043)\end{array}$ & $\begin{array}{l}-0.044 \\
(0.029)\end{array}$ & $\begin{array}{l}-0.060^{* *} \\
(0.026)\end{array}$ & $\begin{array}{l}-0.063^{* *} \\
(0.027)\end{array}$ \\
\hline Constant & $\begin{array}{l}21.512^{\text {*** }} \\
(2.415)\end{array}$ & $\begin{array}{l}22.301^{* * *} \\
(1.882)\end{array}$ & $\begin{array}{l}23.400^{* * *} \\
(2.055)\end{array}$ & $\begin{array}{l}9.902^{* * *} \\
(1.480)\end{array}$ & $\begin{array}{l}9.087^{* * *} \\
(1.148)\end{array}$ & $\begin{array}{l}9.610^{* * *} \\
(1.286)\end{array}$ \\
\hline Observations & 85 & 85 & 85 & 84 & 84 & 84 \\
\hline \multirow[t]{4}{*}{ R-squared } & 0.06 & 0.15 & 0.15 & 0.20 & 0.28 & 0.25 \\
\hline & \multicolumn{6}{|c|}{ Panel B - Entrepreneurship } \\
\hline & (1) & (2) & $(3)$ & $(4)$ & $(5)$ & $(6)$ \\
\hline & \multicolumn{3}{|c|}{ Business Density } & \multicolumn{3}{|c|}{ Average entry rate $2000-04$} \\
\hline Statutory Corporate Tax Rate & $\begin{array}{l}-0.165^{\star *} \\
(0.066)\end{array}$ & & & $\begin{array}{l}-0.135^{\star *} \\
(0.065)\end{array}$ & & \\
\hline 1st Year Effective Tax Rate & & $\begin{array}{l}-0.195^{\star \star \star} \\
(0.063)\end{array}$ & & & $\begin{array}{l}-0.137^{* *} \\
(0.058)\end{array}$ & \\
\hline 5-Year Effective Tax Rate & & & $\begin{array}{l}-0.200^{* * *} \\
(0.068)\end{array}$ & & & $\begin{array}{l}-0.135^{* *} \\
(0.062)\end{array}$ \\
\hline PIT top marginal rate & $\begin{array}{l}0.023 \\
(0.041)\end{array}$ & $\begin{array}{l}0.008 \\
(0.038)\end{array}$ & $\begin{array}{l}0.003 \\
(0.038)\end{array}$ & $\begin{array}{l}0.015 \\
(0.042)\end{array}$ & $\begin{array}{l}0.001 \\
(0.039)\end{array}$ & $\begin{array}{l}-0.006 \\
(0.039)\end{array}$ \\
\hline Constant & $\begin{array}{l}9.035^{\star * *} \\
(2.028)\end{array}$ & $\begin{array}{l}8.162^{* * *} \\
(1.634)\end{array}$ & $\begin{array}{l}8.810^{* * *} \\
(1.802)\end{array}$ & $\begin{array}{l}11.556^{* * *} \\
(1.940)\end{array}$ & $\begin{array}{l}10.427^{* * *} \\
(1.549)\end{array}$ & $\begin{array}{l}10.935^{\text {*** }} \\
(1.718)\end{array}$ \\
\hline Observations & 80 & 80 & 80 & 62 & 62 & 62 \\
\hline R-squared & 0.07 & 0.11 & 0.10 & 0.07 & 0.09 & 0.08 \\
\hline
\end{tabular}

Standard errors in parentheses

${ }^{*}$ significant at $10 \%$; ${ }^{* *}$ significant at $5 \%$; ${ }^{* * *}$ significant at $1 \%$ 
Table 5d. Log Number of Tax Payments

\begin{tabular}{|c|c|c|c|c|c|c|}
\hline & \multicolumn{6}{|c|}{ Panel A - Investment } \\
\hline & (1) & (2) & $(3)$ & $(4)$ & (5) & (6) \\
\hline & \multicolumn{3}{|c|}{ Investment 2003-05 } & \multicolumn{3}{|c|}{ FDI 2003-05 } \\
\hline Statutory Corporate Tax Rate & $\begin{array}{l}-0.076 \\
(0.077)\end{array}$ & & & $\begin{array}{l}-0.194^{\star * *} \\
(0.047)\end{array}$ & & \\
\hline 1st Year Effective Tax Rate & & $\begin{array}{l}-0.226^{* * *} \\
(0.075)\end{array}$ & & & $\begin{array}{l}-0.226^{* * *} \\
(0.046)\end{array}$ & \\
\hline 5-Year Effective Tax Rate & & & $\begin{array}{l}-0.250^{* * *} \\
(0.080)\end{array}$ & & & $\begin{array}{l}-0.222^{* * *} \\
(0.050)\end{array}$ \\
\hline Log of number of tax payments & $\begin{array}{l}0.359 \\
(0.688)\end{array}$ & $\begin{array}{l}0.576 \\
(0.660)\end{array}$ & $\begin{array}{l}0.422 \\
(0.652)\end{array}$ & $\begin{array}{l}-0.093 \\
(0.418)\end{array}$ & $\begin{array}{l}0.023 \\
(0.406)\end{array}$ & $\begin{array}{l}-0.152 \\
(0.412)\end{array}$ \\
\hline Constant & $\begin{array}{l}22.480^{* * *} \\
(3.066)\end{array}$ & $\begin{array}{l}23.496^{\star \star *} \\
(2.433)\end{array}$ & $\begin{array}{l}24.938^{\star * * *} \\
(2.628)\end{array}$ & $\begin{array}{l}9.322^{* \star *} \\
(1.866)\end{array}$ & $\begin{array}{l}7.222^{\star * *} \\
(1.497)\end{array}$ & $\begin{array}{l}8.199^{\star * *} \\
(1.662)\end{array}$ \\
\hline Observations & 85 & 85 & 85 & 84 & 84 & 84 \\
\hline \multirow[t]{4}{*}{ R-squared } & 0.01 & 0.10 & 0.11 & 0.18 & 0.23 & 0.20 \\
\hline & \multicolumn{6}{|c|}{ Panel B - Entrepreneurship } \\
\hline & (1) & (2) & (3) & (4) & $(5)$ & (6) \\
\hline & \multicolumn{3}{|c|}{ Business Density } & \multicolumn{3}{|c|}{ Average entry rate $2000-04$} \\
\hline$\overline{\text { Statutory Corporate Tax Rate }}$ & $\begin{array}{l}-0.133^{* *} \\
(0.058)\end{array}$ & & & $\begin{array}{l}-0.119^{* *} \\
(0.055)\end{array}$ & & \\
\hline 1st Year Effective Tax Rate & & $\begin{array}{l}-0.161^{* * *} \\
(0.059)\end{array}$ & & & $\begin{array}{l}-0.121^{* *} \\
(0.052)\end{array}$ & \\
\hline 5-Year Effective Tax Rate & & & $\begin{array}{l}-0.184^{* * *} \\
(0.062)\end{array}$ & & & $\begin{array}{l}-0.134^{* *} \\
(0.056)\end{array}$ \\
\hline Log of number of tax payments & $\begin{array}{l}-2.005^{* * *} \\
(0.525)\end{array}$ & $\begin{array}{l}-1.896^{* * *} \\
(0.522)\end{array}$ & $\begin{array}{l}-2.015^{* * *} \\
(0.514)\end{array}$ & $\begin{array}{l}-1.652^{* * *} \\
(0.471)\end{array}$ & $\begin{array}{l}-1.594^{* * *} \\
(0.470)\end{array}$ & $\begin{array}{l}-1.680^{* * *} \\
(0.467)\end{array}$ \\
\hline Constant & $\begin{array}{l}15.495^{\star * *} \\
(2.334)\end{array}$ & $\begin{array}{l}14.072^{* * *} \\
(1.901)\end{array}$ & $\begin{array}{l}15.237^{* * *} \\
(2.048)\end{array}$ & $\begin{array}{l}16.915^{\text {*** }} \\
(2.194)\end{array}$ & $\begin{array}{l}15.312^{* * *} \\
(1.729)\end{array}$ & $\begin{array}{l}16.137^{\star * *} \\
(1.884)\end{array}$ \\
\hline Observations & 80 & 80 & 80 & 62 & 62 & 62 \\
\hline R-squared & 0.22 & 0.24 & 0.25 & 0.23 & 0.24 & 0.24 \\
\hline
\end{tabular}

Standard errors in parentheses

${ }^{*}$ significant at $10 \%$; ${ }^{* *}$ significant at $5 \%$; ${ }^{* * *}$ significant at $1 \%$ 
Table 5e. Tax Evasion (GCR)

\begin{tabular}{lllllll} 
& \multicolumn{7}{c}{ Panel A - Investment } \\
& \multicolumn{1}{c}{$(1)$} & \multicolumn{1}{c}{$(2)$} & \multicolumn{1}{c}{$(3)$} & \multicolumn{1}{c}{$(4)$} & \multicolumn{1}{c}{$(5)$} & $(6)$ \\
\hline & \multicolumn{2}{c}{ Investment 2003-05 } & \multicolumn{3}{c}{ FDI 2003-05 } \\
\hline Statutory Corporate Tax Rate & -0.075 & & $-0.159^{* * *}$ \\
& $(0.088)$ & & $(0.054)$ & \\
1st Year Effective Tax Rate & & $-0.167^{*}$ & & & $-0.190^{* * *}$ \\
& & $(0.090)$ & & & $(0.055)$ \\
5-Year Effective Tax Rate & & & $-0.214^{* *}$ & & & $-0.182^{* * *}$ \\
& & & $(0.095)$ & & & $(0.059)$ \\
Tax evasion (GCR) & 0.204 & 0.102 & 0.251 & $0.674^{* *}$ & $0.580^{*}$ & $0.748^{* *}$ \\
& $(0.533)$ & $(0.525)$ & $(0.514)$ & $(0.324)$ & $(0.319)$ & $(0.322)$ \\
Constant & $22.712^{* * *}$ & $23.831^{* * *}$ & $24.547^{* * *}$ & $5.529^{* * *}$ & $4.576^{* * *}$ & $4.221^{* *}$ \\
& $(3.282)$ & $(2.619)$ & $(2.597)$ & $(1.995)$ & $(1.588)$ & $(1.624)$ \\
Observations & 64 & 64 & 64 & 63 & 63 & 63 \\
R-squared & 0.01 & 0.06 & 0.08 & 0.19 & 0.22 & 0.20 \\
\hline
\end{tabular}

\begin{tabular}{lllllll} 
& \multicolumn{6}{c}{ Panel B - Entrepreneurship } \\
& \multicolumn{1}{c}{$(1)$} & $(2)$ & $(3)$ & $(4)$ & $(5)$ & \multicolumn{1}{c}{$(6)$} \\
\hline Statutory Corporate Tax Rate & -0.079 & \multicolumn{5}{c}{ Average entry rate 2000-04 } \\
& $(0.066)$ & & \multicolumn{3}{c}{$-0.149^{* *}$} & $(0.061)$ \\
1st Year Effective Tax Rate & & $-0.154^{* *}$ & & & $-0.131^{* *}$ \\
& & $(0.067)$ & & & $(0.062)$ \\
5-Year Effective Tax Rate & & & $-0.158^{* *}$ & & & $-0.157^{* *}$ \\
& & & $(0.072)$ & & & $(0.065)$ \\
Tax evasion (GCR) & $1.303^{* * *}$ & $1.203^{* * *}$ & $1.347^{* * *}$ & $0.859^{* *}$ & $0.745^{*}$ & $0.866^{* *}$ \\
& $(0.402)$ & $(0.393)$ & $(0.390)$ & $(0.366)$ & $(0.374)$ & $(0.367)$ \\
Constant & 3.299 & $4.086^{* *}$ & $3.948^{* *}$ & $9.585^{* * *}$ & $7.900^{* * *}$ & $8.280^{* * *}$ \\
& $(2.464)$ & $(1.969)$ & $(1.968)$ & $(2.221)$ & $(1.847)$ & $(1.844)$ \\
Observations & 63 & 63 & 63 & 51 & 51 & 51 \\
R-squared & 0.17 & 0.22 & 0.22 & 0.19 & 0.17 & 0.19 \\
\hline
\end{tabular}

Standard errors in parentheses

${ }^{*}$ significant at $10 \%$; ${ }^{* *}$ significant at $5 \%$; ${ }^{* * *}$ significant at $1 \%$ 
Table 5f. Log GDP per capita in 2003

\begin{tabular}{|c|c|c|c|c|c|c|}
\hline & \multicolumn{6}{|c|}{ Panel A - Investment } \\
\hline & $(1)$ & $(2)$ & $(3)$ & $(4)$ & (5) & (6) \\
\hline & \multicolumn{3}{|c|}{ Investment 2003-05 } & \multicolumn{3}{|c|}{ FDI 2003-05 } \\
\hline Statutory Corporate Tax Rate & $\begin{array}{l}-0.073 \\
(0.076)\end{array}$ & & & $\begin{array}{l}-0.195^{\star \star \star} \\
(0.046)\end{array}$ & & \\
\hline 1st Year Effective Tax Rate & & $\begin{array}{l}-0.222^{* * *} \\
(0.074)\end{array}$ & & & $\begin{array}{l}-0.225^{\star * *} \\
(0.046)\end{array}$ & \\
\hline 5-Year Effective Tax Rate & & & $\begin{array}{l}-0.251^{* * *} \\
(0.080)\end{array}$ & & & $\begin{array}{l}-0.223^{* * *} \\
(0.050)\end{array}$ \\
\hline Log GDP pc 2003 & $\begin{array}{l}-0.241 \\
(0.325)\end{array}$ & $\begin{array}{l}-0.293 \\
(0.311)\end{array}$ & $\begin{array}{l}-0.286 \\
(0.309)\end{array}$ & $\begin{array}{l}0.082 \\
(0.197)\end{array}$ & $\begin{array}{l}0.035 \\
(0.192)\end{array}$ & $\begin{array}{l}0.052 \\
(0.196)\end{array}$ \\
\hline Constant & $\begin{array}{l}25.534^{* * *} \\
(3.516)\end{array}$ & $\begin{array}{l}27.689^{* * *} \\
(2.940)\end{array}$ & $\begin{array}{l}28.657^{* * *} \\
(3.049)\end{array}$ & $\begin{array}{l}8.372^{* * *} \\
(2.128)\end{array}$ & $\begin{array}{l}7.002^{* * *} \\
(1.808)\end{array}$ & $\begin{array}{l}7.282^{* * *} \\
(1.927)\end{array}$ \\
\hline Observations & 85 & 85 & 85 & 84 & 84 & 84 \\
\hline \multirow[t]{4}{*}{ R-squared } & 0.02 & 0.10 & 0.11 & 0.18 & 0.23 & 0.20 \\
\hline & \multicolumn{6}{|c|}{ Panel B - Entrepreneurship } \\
\hline & (1) & (2) & $(3)$ & $(4)$ & $(5)$ & $(6)$ \\
\hline & \multicolumn{3}{|c|}{ Business Density } & \multicolumn{3}{|c|}{ Average entry rate $2000-04$} \\
\hline Statutory Corporate Tax Rate & $\begin{array}{l}-0.160^{\star * *} \\
(0.051)\end{array}$ & & & $\begin{array}{l}-0.136^{* *} \\
(0.058)\end{array}$ & & \\
\hline 1st Year Effective Tax Rate & & $\begin{array}{l}-0.180^{* * *} \\
(0.051)\end{array}$ & & & $\begin{array}{l}-0.140^{* *} \\
(0.055)\end{array}$ & \\
\hline 5-Year Effective Tax Rate & & & $\begin{array}{l}-0.192^{* * *} \\
(0.055)\end{array}$ & & & $\begin{array}{l}-0.138^{* *} \\
(0.059)\end{array}$ \\
\hline Log GDP pc 2003 & $\begin{array}{l}1.476^{* * *} \\
(0.230)\end{array}$ & $\begin{array}{l}1.428^{* * *} \\
(0.227)\end{array}$ & $\begin{array}{l}1.444^{* * *} \\
(0.227)\end{array}$ & $\begin{array}{l}0.556^{\star *} \\
(0.247)\end{array}$ & $\begin{array}{l}0.528^{\star *} \\
(0.245)\end{array}$ & $\begin{array}{l}0.521^{* *} \\
(0.247)\end{array}$ \\
\hline Constant & $\begin{array}{l}-2.465 \\
(2.398)\end{array}$ & $\begin{array}{l}-3.575^{\star} \\
(2.124)\end{array}$ & $\begin{array}{l}-3.102 \\
(2.195)\end{array}$ & $\begin{array}{l}7.451^{* * *} \\
(2.598)\end{array}$ & $\begin{array}{l}6.091^{* * *} \\
(2.260)\end{array}$ & $\begin{array}{l}6.456^{* * *} \\
(2.383)\end{array}$ \\
\hline Observations & 80 & 80 & 80 & 62 & 62 & 62 \\
\hline R-squared & 0.39 & 0.41 & 0.41 & 0.14 & 0.16 & 0.14 \\
\hline
\end{tabular}

Standard errors in parentheses

${ }^{*}$ significant at $10 \%$; ${ }^{* *}$ significant at $5 \%$; ${ }^{* * *}$ significant at $1 \%$ 
Table 5g. IEF Property Rights Index

\begin{tabular}{|c|c|c|c|c|c|c|}
\hline & \multicolumn{6}{|c|}{ Panel A - Investment } \\
\hline & $(1)$ & $(2)$ & $(3)$ & $(4)$ & (5) & (6) \\
\hline & \multicolumn{3}{|c|}{ Investment 2003-05 } & \multicolumn{3}{|c|}{ FDI 2003-05 } \\
\hline Statutory Corporate Tax Rate & $\begin{array}{l}-0.070 \\
(0.077)\end{array}$ & & & $\begin{array}{l}-0.195^{\star \star \star} \\
(0.046)\end{array}$ & & \\
\hline 1st Year Effective Tax Rate & & $\begin{array}{l}-0.220^{* \star *} \\
(0.074)\end{array}$ & & & $\begin{array}{l}-0.226^{* * *} \\
(0.046)\end{array}$ & \\
\hline 5-Year Effective Tax Rate & & & $\begin{array}{l}-0.245^{\star * *} \\
(0.080)\end{array}$ & & & $\begin{array}{l}-0.223^{* * *} \\
(0.050)\end{array}$ \\
\hline IEF Property Rights Index & $\begin{array}{l}-0.016 \\
(0.022)\end{array}$ & $\begin{array}{l}-0.019 \\
(0.021)\end{array}$ & $\begin{array}{l}-0.015 \\
(0.021)\end{array}$ & $\begin{array}{l}-0.001 \\
(0.014)\end{array}$ & $\begin{array}{l}-0.006 \\
(0.013)\end{array}$ & $\begin{array}{l}-0.001 \\
(0.013)\end{array}$ \\
\hline Constant & $\begin{array}{l}24.338^{* * *} \\
(2.541)\end{array}$ & $\begin{array}{l}26.338^{* * *} \\
(1.843)\end{array}$ & $\begin{array}{l}27.041^{* * *} \\
(1.973)\end{array}$ & $\begin{array}{l}9.074^{* * *} \\
(1.540)\end{array}$ & $\begin{array}{l}7.638^{* * *} \\
(1.129)\end{array}$ & $\begin{array}{l}7.793^{* * *} \\
(1.243)\end{array}$ \\
\hline Observations & 85 & 85 & 85 & 84 & 84 & 84 \\
\hline \multirow[t]{4}{*}{ R-squared } & 0.02 & 0.10 & 0.11 & 0.18 & 0.23 & 0.20 \\
\hline & \multicolumn{6}{|c|}{ Panel B - Entrepreneurship } \\
\hline & (1) & (2) & $(3)$ & $(4)$ & $(5)$ & $(6)$ \\
\hline & \multicolumn{3}{|c|}{ Business Density } & \multicolumn{3}{|c|}{ Average entry rate $2000-04$} \\
\hline Statutory Corporate Tax Rate & $\begin{array}{l}-0.169^{* * *} \\
(0.054)\end{array}$ & & & $\begin{array}{l}-0.138^{* *} \\
(0.057)\end{array}$ & & \\
\hline 1st Year Effective Tax Rate & & $\begin{array}{l}-0.180^{* \star *} \\
(0.055)\end{array}$ & & & $\begin{array}{l}-0.133^{* *} \\
(0.055)\end{array}$ & \\
\hline 5-Year Effective Tax Rate & & & $\begin{array}{l}-0.212^{* * *} \\
(0.058)\end{array}$ & & & $\begin{array}{l}-0.140^{* *} \\
(0.059)\end{array}$ \\
\hline IEF Property Rights Index & $\begin{array}{l}0.085^{\star * *} \\
(0.016)\end{array}$ & $\begin{array}{l}0.080^{* * *} \\
(0.016)\end{array}$ & $\begin{array}{l}0.085^{\star * *} \\
(0.016)\end{array}$ & $\begin{array}{l}0.041^{* *} \\
(0.017)\end{array}$ & $\begin{array}{l}0.037^{* *} \\
(0.016)\end{array}$ & $\begin{array}{l}0.039^{* *} \\
(0.016)\end{array}$ \\
\hline Constant & $\begin{array}{l}5.244^{* * *} \\
(1.801)\end{array}$ & $\begin{array}{l}3.772^{* * *} \\
(1.384)\end{array}$ & $\begin{array}{l}4.487^{* * *} \\
(1.447)\end{array}$ & $\begin{array}{l}9.769^{* * *} \\
(1.900)\end{array}$ & $\begin{array}{l}8.262^{* * *} \\
(1.407)\end{array}$ & $\begin{array}{l}8.590^{* * *} \\
(1.520)\end{array}$ \\
\hline Observations & 80 & 80 & 80 & 62 & 62 & 62 \\
\hline R-squared & 0.32 & 0.32 & 0.34 & 0.16 & 0.16 & 0.16 \\
\hline
\end{tabular}

Standard errors in parentheses

${ }^{*}$ significant at $10 \%$; ${ }^{* *}$ significant at $5 \%$; ${ }^{* *}$ significant at $1 \%$ 
Table 5h. Procedures to start a business

\begin{tabular}{|c|c|c|c|c|c|c|}
\hline & \multicolumn{6}{|c|}{ Panel A - Investment } \\
\hline & (1) & $(2)$ & $(3)$ & $(4)$ & (5) & (6) \\
\hline & \multicolumn{3}{|c|}{ Investment 2003-05 } & \multicolumn{3}{|c|}{ FDI 2003-05 } \\
\hline Statutory Corporate Tax Rate & $\begin{array}{l}-0.066 \\
(0.079)\end{array}$ & & & $\begin{array}{l}-0.197^{\star \star \star} \\
(0.047)\end{array}$ & & \\
\hline 1st Year Effective Tax Rate & & $\begin{array}{l}-0.222^{* * *} \\
(0.077)\end{array}$ & & & $\begin{array}{l}-0.225^{\star * *} \\
(0.047)\end{array}$ & \\
\hline 5-Year Effective Tax Rate & & & $\begin{array}{l}-0.246^{* * *} \\
(0.081)\end{array}$ & & & $\begin{array}{l}-0.221^{\text {***}} \\
(0.050)\end{array}$ \\
\hline Procedures to start a business & $\begin{array}{l}0.023 \\
(0.151)\end{array}$ & $\begin{array}{l}0.089 \\
(0.146)\end{array}$ & $\begin{array}{l}0.051 \\
(0.144)\end{array}$ & $\begin{array}{l}-0.090 \\
(0.090)\end{array}$ & $\begin{array}{l}-0.055 \\
(0.089)\end{array}$ & $\begin{array}{l}-0.099 \\
(0.089)\end{array}$ \\
\hline Constant & $\begin{array}{l}23.202^{* * *} \\
(2.557)\end{array}$ & $\begin{array}{l}24.534^{* * *} \\
(1.770)\end{array}$ & $\begin{array}{l}25.815^{\star * *} \\
(2.010)\end{array}$ & $\begin{array}{l}9.882^{* * *} \\
(1.533)\end{array}$ & $\begin{array}{l}7.757^{* * *} \\
(1.075)\end{array}$ & $\begin{array}{l}8.562^{* * *} \\
(1.254)\end{array}$ \\
\hline Observations & 84 & 84 & 84 & 83 & 83 & 83 \\
\hline \multirow[t]{4}{*}{ R-squared } & 0.01 & 0.09 & 0.10 & 0.20 & 0.24 & 0.21 \\
\hline & \multicolumn{6}{|c|}{ Panel B - Entrepreneurship } \\
\hline & (1) & $(2)$ & $(3)$ & $(4)$ & $(5)$ & $(6)$ \\
\hline & \multicolumn{3}{|c|}{ Business Density } & \multicolumn{3}{|c|}{ Average entry rate $2000-04$} \\
\hline Statutory Corporate Tax Rate & $\begin{array}{l}-0.126^{* *} \\
(0.060)\end{array}$ & & & $\begin{array}{l}-0.113^{*} \\
(0.057)\end{array}$ & & \\
\hline 1st Year Effective Tax Rate & & $\begin{array}{l}-0.153^{* *} \\
(0.060)\end{array}$ & & & $\begin{array}{l}-0.110^{*} \\
(0.055)\end{array}$ & \\
\hline 5-Year Effective Tax Rate & & & $\begin{array}{l}-0.177^{\star * *} \\
(0.063)\end{array}$ & & & $\begin{array}{l}-0.121^{* *} \\
(0.058)\end{array}$ \\
\hline Procedures to start a business & $\begin{array}{l}-0.428^{* * *} \\
(0.117)\end{array}$ & $\begin{array}{l}-0.401^{* * *} \\
(0.116)\end{array}$ & $\begin{array}{l}-0.428^{* * *} \\
(0.114)\end{array}$ & $\begin{array}{l}-0.321^{* * *} \\
(0.114)\end{array}$ & $\begin{array}{l}-0.297^{* *} \\
(0.116)\end{array}$ & $\begin{array}{l}-0.319^{* * *} \\
(0.114)\end{array}$ \\
\hline Constant & $\begin{array}{l}12.562^{* * *} \\
(1.954)\end{array}$ & $\begin{array}{l}11.333^{* * *} \\
(1.394)\end{array}$ & $\begin{array}{l}12.355^{* * *} \\
(1.578)\end{array}$ & $\begin{array}{l}14.107^{* * *} \\
(1.882)\end{array}$ & $\begin{array}{l}12.494^{* * *} \\
(1.281)\end{array}$ & $\begin{array}{l}13.154^{* * *} \\
(1.469)\end{array}$ \\
\hline Observations & 79 & 79 & 79 & 62 & 62 & 62 \\
\hline R-squared & 0.21 & 0.23 & 0.24 & 0.18 & 0.18 & 0.18 \\
\hline
\end{tabular}

Standard errors in parentheses

${ }^{*}$ significant at $10 \%$; ${ }^{* *}$ significant at $5 \%$; ${ }^{* * *}$ significant at $1 \%$ 
Table 5i. Employment rigidity index

\begin{tabular}{|c|c|c|c|c|c|c|}
\hline & \multicolumn{6}{|c|}{ Panel A - Investment } \\
\hline & $(1)$ & $(2)$ & $(3)$ & $(4)$ & (5) & $(6)$ \\
\hline & \multicolumn{3}{|c|}{ Investment 2003-05 } & \multicolumn{3}{|c|}{ FDI 2003-05 } \\
\hline Statutory Corporate Tax Rate & $\begin{array}{l}-0.072 \\
(0.076)\end{array}$ & & & $\begin{array}{l}-0.194^{* * *} \\
(0.045)\end{array}$ & & \\
\hline 1st Year Effective Tax Rate & & $\begin{array}{l}-0.216^{\star * *} \\
(0.074)\end{array}$ & & & $\begin{array}{l}-0.223^{\star * *} \\
(0.044)\end{array}$ & \\
\hline 5-Year Effective Tax Rate & & & $\begin{array}{l}-0.261^{* * *} \\
(0.080)\end{array}$ & & & $\begin{array}{l}-0.244^{\star * *} \\
(0.048)\end{array}$ \\
\hline Rigidity of employment & $\begin{array}{l}-0.022 \\
(0.030)\end{array}$ & $\begin{array}{l}-0.020 \\
(0.029)\end{array}$ & $\begin{array}{l}-0.035 \\
(0.029)\end{array}$ & $\begin{array}{l}-0.041^{* *} \\
(0.018)\end{array}$ & $\begin{array}{l}-0.040^{* *} \\
(0.017)\end{array}$ & $\begin{array}{l}-0.054^{* * *} \\
(0.017)\end{array}$ \\
\hline Constant & $\begin{array}{l}24.356^{* * *} \\
(2.529)\end{array}$ & $\begin{array}{l}25.980^{* * *} \\
(1.733)\end{array}$ & $\begin{array}{l}27.846^{* * *} \\
(2.065)\end{array}$ & $\begin{array}{l}10.501^{* * *} \\
(1.485)\end{array}$ & $\begin{array}{l}8.730^{* * *} \\
(1.027)\end{array}$ & $\begin{array}{l}10.105^{\text {*** }} \\
(1.237)\end{array}$ \\
\hline Observations & 85 & 85 & 85 & 84 & 84 & 84 \\
\hline \multirow[t]{4}{*}{ R-squared } & 0.02 & 0.10 & 0.12 & 0.23 & 0.28 & 0.28 \\
\hline & \multicolumn{6}{|c|}{ Panel B - Entrepreneurship } \\
\hline & (1) & $(2)$ & $(3)$ & $(4)$ & $(5)$ & (6) \\
\hline & \multicolumn{3}{|c|}{ Business Density } & \multicolumn{3}{|c|}{ Average entry rate $2000-04$} \\
\hline Statutory Corporate Tax Rate & $\begin{array}{l}-0.153^{* *} \\
(0.062)\end{array}$ & & & $\begin{array}{l}-0.136^{* *} \\
(0.058)\end{array}$ & & \\
\hline 1st Year Effective Tax Rate & & $\begin{array}{l}-0.191^{* * *} \\
(0.062)\end{array}$ & & & $\begin{array}{l}-0.137^{* *} \\
(0.055)\end{array}$ & \\
\hline 5-Year Effective Tax Rate & & & $\begin{array}{l}-0.220^{* * *} \\
(0.067)\end{array}$ & & & $\begin{array}{l}-0.162^{* * *} \\
(0.060)\end{array}$ \\
\hline Rigidity of employment & $\begin{array}{l}-0.039 \\
(0.025)\end{array}$ & $\begin{array}{l}-0.038 \\
(0.024)\end{array}$ & $\begin{array}{l}-0.051^{* *} \\
(0.024)\end{array}$ & $\begin{array}{l}-0.046^{*} \\
(0.023)\end{array}$ & $\begin{array}{l}-0.042^{*} \\
(0.023)\end{array}$ & $\begin{array}{l}-0.053^{* *} \\
(0.023)\end{array}$ \\
\hline Constant & $\begin{array}{l}10.923^{* * \star} \\
(2.058)\end{array}$ & $\begin{array}{l}9.750^{\star \star *} \\
(1.443)\end{array}$ & $\begin{array}{l}11.167^{* \star *} \\
(1.724)\end{array}$ & $\begin{array}{l}13.712^{\star \star \star} \\
(1.996)\end{array}$ & $\begin{array}{l}11.933^{* * *} \\
(1.315)\end{array}$ & $\begin{array}{l}13.141^{\text {*** }} \\
(1.603)\end{array}$ \\
\hline Observations & 80 & 80 & 80 & 62 & 62 & 62 \\
\hline R-squared & 0.10 & 0.14 & 0.15 & 0.13 & 0.14 & 0.15 \\
\hline
\end{tabular}

Standard errors in parentheses

${ }^{*}$ significant at $10 \%$; ${ }^{* *}$ significant at $5 \%$; ${ }^{* * *}$ significant at $1 \%$ 
Table 5j. Average Inflation 1995-2004

\begin{tabular}{|c|c|c|c|c|c|c|}
\hline & \multicolumn{6}{|c|}{ Panel A - Investment } \\
\hline & (1) & (2) & (3) & $(4)$ & (5) & (6) \\
\hline & \multicolumn{3}{|c|}{ Investment 2003-05 } & \multicolumn{3}{|c|}{ FDI 2003-05 } \\
\hline Statutory Corporate Tax Rate & $\begin{array}{l}-0.087 \\
(0.077)\end{array}$ & & & $\begin{array}{l}-0.192^{\star \star \star} \\
(0.047)\end{array}$ & & \\
\hline 1st Year Effective Tax Rate & & $\begin{array}{l}-0.241^{* * *} \\
(0.075)\end{array}$ & & & $\begin{array}{l}-0.223^{* * *} \\
(0.046)\end{array}$ & \\
\hline 5-Year Effective Tax Rate & & & $\begin{array}{l}-0.275^{\star * *} \\
(0.080)\end{array}$ & & & $\begin{array}{l}-0.220^{* * *} \\
(0.051)\end{array}$ \\
\hline Average inflation (1995-2004) & $\begin{array}{l}-0.036 \\
(0.026)\end{array}$ & $\begin{array}{l}-0.046^{*} \\
(0.025)\end{array}$ & $\begin{array}{l}-0.047^{*} \\
(0.024)\end{array}$ & $\begin{array}{l}0.009 \\
(0.016)\end{array}$ & $\begin{array}{l}0.004 \\
(0.015)\end{array}$ & $\begin{array}{l}0.005 \\
(0.016)\end{array}$ \\
\hline Constant & $\begin{array}{l}24.492^{* \star *} \\
(2.360)\end{array}$ & $\begin{array}{l}26.280^{\star * *} \\
(1.476)\end{array}$ & $\begin{array}{l}27.459^{* * *} \\
(1.715)\end{array}$ & $\begin{array}{l}8.830^{* * *} \\
(1.432)\end{array}$ & $\begin{array}{l}7.199^{* * *} \\
(0.914)\end{array}$ & $\begin{array}{l}7.594^{* * *} \\
(1.096)\end{array}$ \\
\hline Observations & 84 & 84 & 84 & 84 & 84 & 84 \\
\hline R-squared & 0.03 & 0.13 & 0.14 & 0.18 & 0.23 & 0.20 \\
\hline
\end{tabular}

\begin{tabular}{|c|c|c|c|c|c|c|}
\hline & \multicolumn{6}{|c|}{ Panel B - Entrepreneurship } \\
\hline & (1) & $(2)$ & (3) & $(4)$ & $(5)$ & (6) \\
\hline & \multicolumn{3}{|c|}{ Business Density } & \multicolumn{3}{|c|}{ Average entry rate $2000-04$} \\
\hline Statutory Corporate Tax Rate & $\begin{array}{l}-0.169^{* * \star} \\
(0.063)\end{array}$ & & & $\begin{array}{l}-0.131^{* *} \\
(0.061)\end{array}$ & & \\
\hline 1st Year Effective Tax Rate & & $\begin{array}{l}-0.215^{\star * *} \\
(0.062)\end{array}$ & & & $\begin{array}{l}-0.142^{* *} \\
(0.058)\end{array}$ & \\
\hline 5-Year Effective Tax Rate & & & $\begin{array}{l}-0.230^{* * *} \\
(0.068)\end{array}$ & & & $\begin{array}{l}-0.141^{\text {** }} \\
(0.063)\end{array}$ \\
\hline Average inflation (1995-2004) & $\begin{array}{l}-0.044^{*} \\
(0.025)\end{array}$ & $\begin{array}{l}-0.048^{*} \\
(0.025)\end{array}$ & $\begin{array}{l}-0.052^{* *} \\
(0.025)\end{array}$ & $\begin{array}{l}-0.007 \\
(0.019)\end{array}$ & $\begin{array}{l}-0.008 \\
(0.019)\end{array}$ & $\begin{array}{l}-0.007 \\
(0.019)\end{array}$ \\
\hline Constant & $\begin{array}{l}10.397^{\star \star \star} \\
(1.948)\end{array}$ & $\begin{array}{l}9.282^{\star * \star} \\
(1.238)\end{array}$ & $\begin{array}{l}10.044^{* * *} \\
(1.471)\end{array}$ & $\begin{array}{l}12.019^{\star \star *} \\
(1.896)\end{array}$ & $\begin{array}{l}10.645^{\star \star \star} \\
(1.143)\end{array}$ & $\begin{array}{l}10.948^{\star * \star} \\
(1.357)\end{array}$ \\
\hline Observations & 79 & 79 & 79 & 62 & 62 & 62 \\
\hline R-squared & 0.10 & 0.15 & 0.15 & 0.07 & 0.09 & 0.08 \\
\hline
\end{tabular}

Standard errors in parentheses

${ }^{*}$ significant at $10 \%$; ${ }^{* *}$ significant at $5 \%$; ${ }^{* *}$ significant at $1 \%$ 
Table 5k. Seignorage 2004

\begin{tabular}{|c|c|c|c|c|c|c|}
\hline & \multicolumn{6}{|c|}{ Panel A - Investment } \\
\hline & $(1)$ & $(2)$ & $(3)$ & $(4)$ & (5) & (6) \\
\hline & \multicolumn{3}{|c|}{ Investment 2003-05 } & \multicolumn{3}{|c|}{ FDI 2003-05 } \\
\hline Statutory Corporate Tax Rate & $\begin{array}{l}-0.081 \\
(0.077)\end{array}$ & & & $\begin{array}{l}-0.170^{\star * *} \\
(0.047)\end{array}$ & & \\
\hline 1st Year Effective Tax Rate & & $\begin{array}{l}-0.194^{* *} \\
(0.075)\end{array}$ & & & $\begin{array}{l}-0.206^{\star * *} \\
(0.046)\end{array}$ & \\
\hline 5-Year Effective Tax Rate & & & $\begin{array}{l}-0.232^{* * *} \\
(0.081)\end{array}$ & & & $\begin{array}{l}-0.196^{\star * *} \\
(0.051)\end{array}$ \\
\hline Seignorage 2004 & $\begin{array}{l}0.364^{* *} \\
(0.147)\end{array}$ & $\begin{array}{l}0.302^{\star *} \\
(0.144)\end{array}$ & $\begin{array}{l}0.300^{* *} \\
(0.142)\end{array}$ & $\begin{array}{l}0.112 \\
(0.089)\end{array}$ & $\begin{array}{l}0.055 \\
(0.087)\end{array}$ & $\begin{array}{l}0.069 \\
(0.090)\end{array}$ \\
\hline Constant & $\begin{array}{l}21.502^{\text {*** }} \\
(2.547)\end{array}$ & $\begin{array}{l}22.918^{* * *} \\
(1.819)\end{array}$ & $\begin{array}{l}24.085^{\star * *} \\
(2.025)\end{array}$ & $\begin{array}{l}7.553^{* * *} \\
(1.550)\end{array}$ & $\begin{array}{l}6.551^{* * *} \\
(1.102)\end{array}$ & $\begin{array}{l}6.708^{* * *} \\
(1.274)\end{array}$ \\
\hline Observations & 81 & 81 & 81 & 81 & 81 & 81 \\
\hline \multirow[t]{4}{*}{ R-squared } & 0.09 & 0.15 & 0.16 & 0.16 & 0.23 & 0.18 \\
\hline & \multicolumn{6}{|c|}{ Panel B - Entrepreneurship } \\
\hline & (1) & $(2)$ & $(3)$ & $(4)$ & $(5)$ & $(6)$ \\
\hline & \multicolumn{3}{|c|}{ Business Density } & \multicolumn{3}{|c|}{ Average entry rate $2000-04$} \\
\hline Statutory Corporate Tax Rate & $\begin{array}{l}-0.153^{* *} \\
(0.065)\end{array}$ & & & $\begin{array}{l}-0.126^{* *} \\
(0.057)\end{array}$ & & \\
\hline 1st Year Effective Tax Rate & & $\begin{array}{l}-0.218^{* * *} \\
(0.063)\end{array}$ & & & $\begin{array}{l}-0.171^{* * *} \\
(0.054)\end{array}$ & \\
\hline 5-Year Effective Tax Rate & & & $\begin{array}{l}-0.220^{* * *} \\
(0.069)\end{array}$ & & & $\begin{array}{l}-0.166^{* * *} \\
(0.058)\end{array}$ \\
\hline Seignorage 2004 & $\begin{array}{l}-0.202 \\
(0.123)\end{array}$ & $\begin{array}{l}-0.263^{* *} \\
(0.121)\end{array}$ & $\begin{array}{l}-0.252^{* *} \\
(0.122)\end{array}$ & $\begin{array}{l}-0.306^{* *} \\
(0.119)\end{array}$ & $\begin{array}{l}-0.378^{* * *} \\
(0.116)\end{array}$ & $\begin{array}{l}-0.361^{* * *} \\
(0.117)\end{array}$ \\
\hline Constant & $\begin{array}{l}10.704^{* * *} \\
(2.144)\end{array}$ & $\begin{array}{l}10.424^{* * *} \\
(1.524)\end{array}$ & $\begin{array}{l}10.852^{* * *} \\
(1.723)\end{array}$ & $\begin{array}{l}13.784^{* * *} \\
(1.890)\end{array}$ & $\begin{array}{l}13.489^{* * *} \\
(1.354)\end{array}$ & $\begin{array}{l}13.680^{* * *} \\
(1.522)\end{array}$ \\
\hline Observations & 77 & 77 & 77 & 61 & 61 & 61 \\
\hline R-squared & 0.09 & 0.16 & 0.14 & 0.17 & 0.23 & 0.21 \\
\hline
\end{tabular}

Standard errors in parentheses

${ }^{*}$ significant at $10 \%$; ${ }^{* *}$ significant at $5 \%$; ${ }^{* * *}$ significant at $1 \%$ 
Table 5I. EFW Freedom to Trade Internationally Index

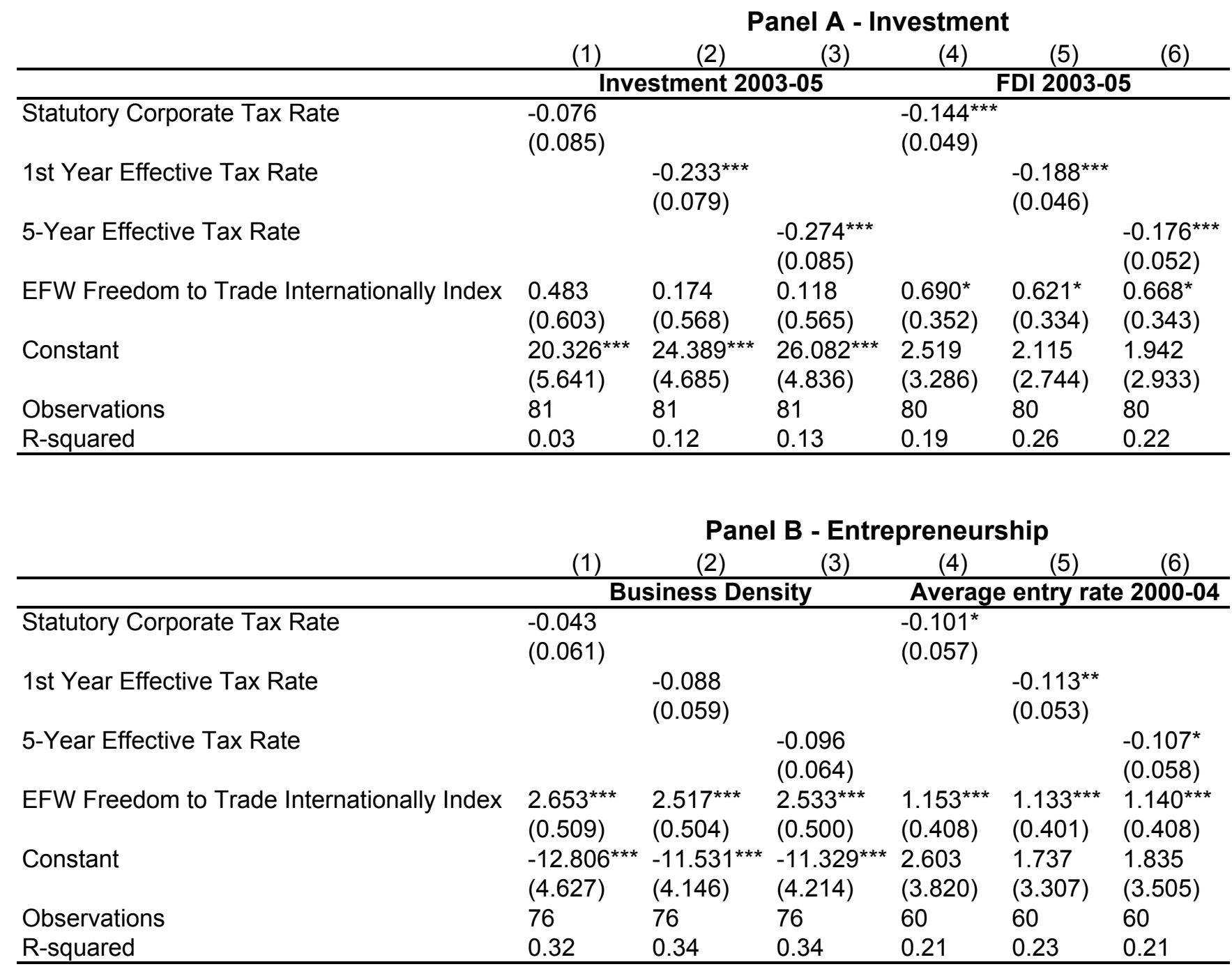

Standard errors in parentheses

${ }^{*}$ significant at $10 \%$; ${ }^{* *}$ significant at $5 \%$; ${ }^{* * *}$ significant at $1 \%$ 
Table 6. Other outcomes

Panel A - Purchases of New Machinery and Equipment as \% of Sales

(1) (2) Manufacturing Sector

\begin{tabular}{|c|c|c|c|c|c|c|}
\hline & \multicolumn{3}{|c|}{ Manufacturing Sector } & \multicolumn{3}{|c|}{ Service Sector } \\
\hline Statutory Corporate Tax Rate & $\begin{array}{r}-0.012 \\
(0.062)\end{array}$ & & & $\begin{array}{r}0.081 \\
(0.066)\end{array}$ & & \\
\hline 1st Year Effective Tax Rate & & $\begin{array}{r}-0.118^{* *} \\
(0.044)\end{array}$ & & & $\begin{array}{r}-0.054 \\
(0.071)\end{array}$ & \\
\hline 5-Year Effective Tax Rate & & & $\begin{array}{r}-0.125^{* *} \\
(0.051)\end{array}$ & & & $\begin{array}{l}-0.013 \\
(0.074)\end{array}$ \\
\hline Constant & $\begin{array}{r}1.470 \\
(1.945)\end{array}$ & $\begin{array}{r}3.458^{* * *} \\
(0.925)\end{array}$ & $\begin{array}{r}3.806^{* * *} \\
(1.146)\end{array}$ & $\begin{array}{l}-1.423 \\
(2.089)\end{array}$ & $\begin{array}{r}2.230 \\
(1.559)\end{array}$ & $\begin{array}{r}1.367 \\
(1.745)\end{array}$ \\
\hline Observations & 31 & 31 & 31 & 20 & 20 & 20 \\
\hline R-squared & 0.00 & 0.20 & 0.17 & 0.08 & 0.03 & 0.00 \\
\hline
\end{tabular}

\section{Panel B - Size of the Informal Sector}

\begin{tabular}{|c|c|c|c|c|c|c|}
\hline & (1) & $(2)$ & (3) & (4) & (5) & $(6)$ \\
\hline & \multicolumn{6}{|c|}{ Size of the Informal Sector } \\
\hline Statutory Corporate Tax Rate & $\begin{array}{c}0.166^{*} \\
(0.089)\end{array}$ & & & $\begin{array}{r}0.087 \\
(0.090)\end{array}$ & & \\
\hline 1st Year Effective Tax Rate & & $\begin{array}{l}0.184^{* *} \\
(0.089)\end{array}$ & & & $\begin{array}{l}0.193^{* *} \\
(0.091)\end{array}$ & \\
\hline 5-Year Effective Tax Rate & & & $\begin{array}{c}0.184^{*} \\
(0.097)\end{array}$ & & & $\begin{array}{r}0.271^{* * *} \\
(0.095)\end{array}$ \\
\hline Log GDP pc 2003 & $\begin{array}{r}-4.405^{\star * *} \\
(0.372)\end{array}$ & $\begin{array}{r}-4.372^{* * *} \\
(0.371)\end{array}$ & $\begin{array}{r}-4.381^{* * *} \\
(0.372)\end{array}$ & & & \\
\hline Tax evasion (GCR) & & & & $\begin{array}{r}-6.286^{* * *} \\
(0.543)\end{array}$ & $\begin{array}{r}-6.168^{* * *} \\
(0.532)\end{array}$ & $\begin{array}{r}-6.342^{* * *} \\
(0.513)\end{array}$ \\
\hline Constant & $\begin{array}{r}58.090^{* * *} \\
(4.045) \\
\end{array}$ & $\begin{array}{r}59.465^{\star * *} \\
(3.500) \\
\end{array}$ & $\begin{array}{r}59.155^{\star \star *} \\
(3.673) \\
\end{array}$ & $\begin{array}{r}44.062^{* * *} \\
(3.342) \\
\end{array}$ & $\begin{array}{r}42.802^{* * *} \\
(2.651) \\
\end{array}$ & $\begin{array}{r}41.510^{\star * *} \\
(2.588) \\
\end{array}$ \\
\hline
\end{tabular}

Standard errors in parentheses

* significant at $10 \%$; ${ }^{* *}$ significant at $5 \%$; ${ }^{* * *}$ significant at $1 \%$ 
Table 7. Debt-to-Equity Ratio

\begin{tabular}{|c|c|c|c|}
\hline & (1) & (2) & (3) \\
\hline & \multicolumn{3}{|c|}{ Debt-to-Equity Ratio } \\
\hline Statutory Corporate Tax Rate & $\begin{array}{l}4.205^{* * *} \\
(1.469)\end{array}$ & & \\
\hline 1st Year Effective Tax Rate & & $\begin{array}{l}3.912^{* *} \\
(1.630)\end{array}$ & \\
\hline 5-Year Effective Tax Rate & & & $\begin{array}{l}2.674 \\
(1.715)\end{array}$ \\
\hline Equity Market Cap in \% of GDP 2003 & $\begin{array}{l}-0.183 \\
(0.183)\end{array}$ & $\begin{array}{l}-0.194 \\
(0.189)\end{array}$ & $\begin{array}{l}-0.318^{*} \\
(0.184)\end{array}$ \\
\hline Log GDP pc 2003 & $\begin{array}{l}28.360^{* * *} \\
(8.104)\end{array}$ & $\begin{array}{l}29.618^{* \star *} \\
(8.253)\end{array}$ & $\begin{array}{l}30.510^{* * *} \\
(8.517)\end{array}$ \\
\hline Constant & $\begin{array}{l}-257.278^{*} \\
(78.153)\end{array}$ & $\begin{array}{l}{ }^{*}-209.359^{\star \star} \\
(74.165)\end{array}$ & $\begin{array}{c}-192.678^{* *} \\
(77.768)\end{array}$ \\
\hline Observations & 50 & 50 & 50 \\
\hline R-squared & 0.34 & 0.31 & 0.26 \\
\hline
\end{tabular}

Standard errors in parentheses

${ }^{*}$ significant at $10 \%$; ${ }^{* *}$ significant at $5 \%$; ${ }^{* * *}$ significant at $1 \%$

Note that we exclude Zimbabwe from this sample as the size of the equity market seems to be blown up due to inflation. When we include Zimbabwe, our results get stronger. 
Figure 1

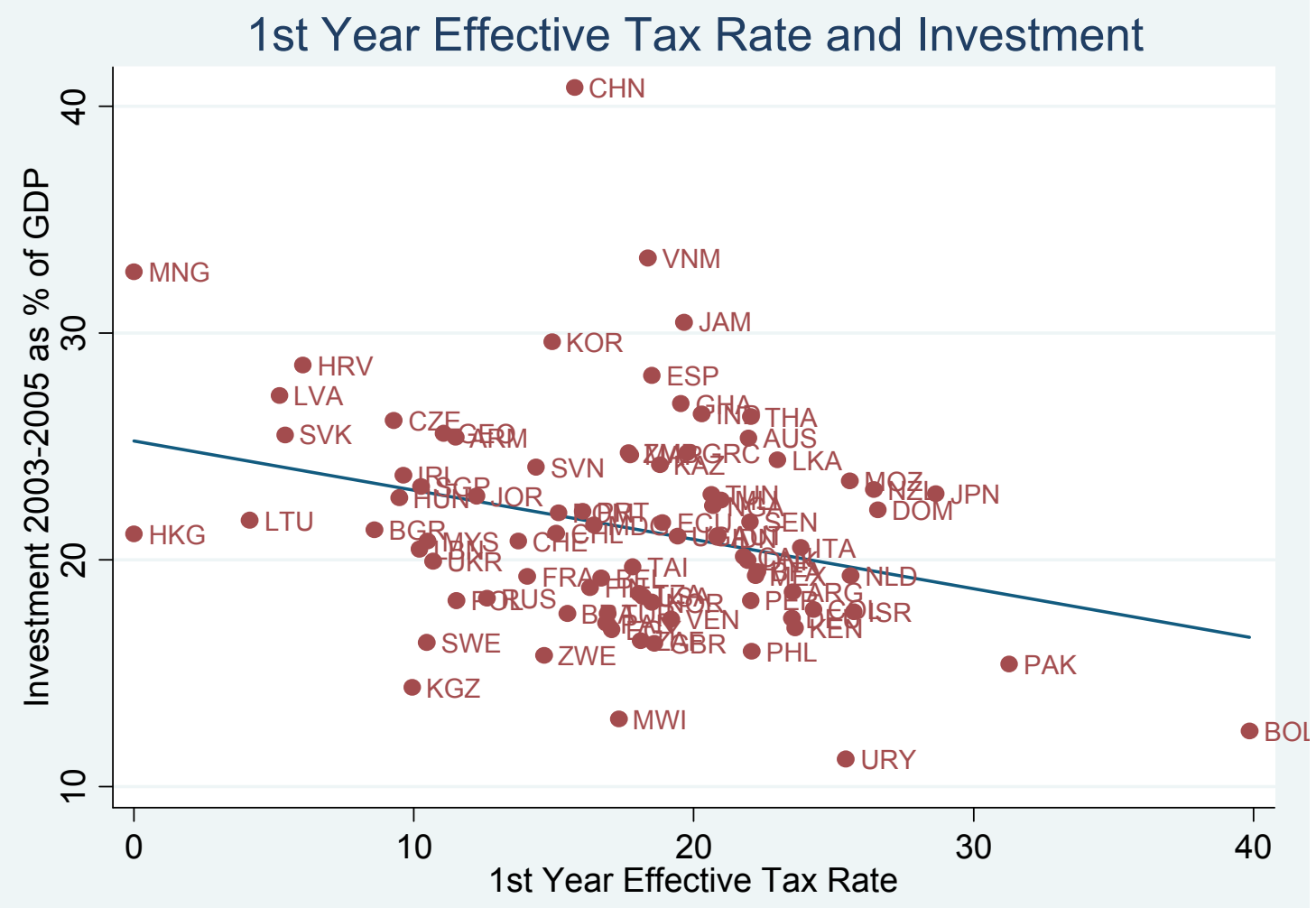

Figure 2

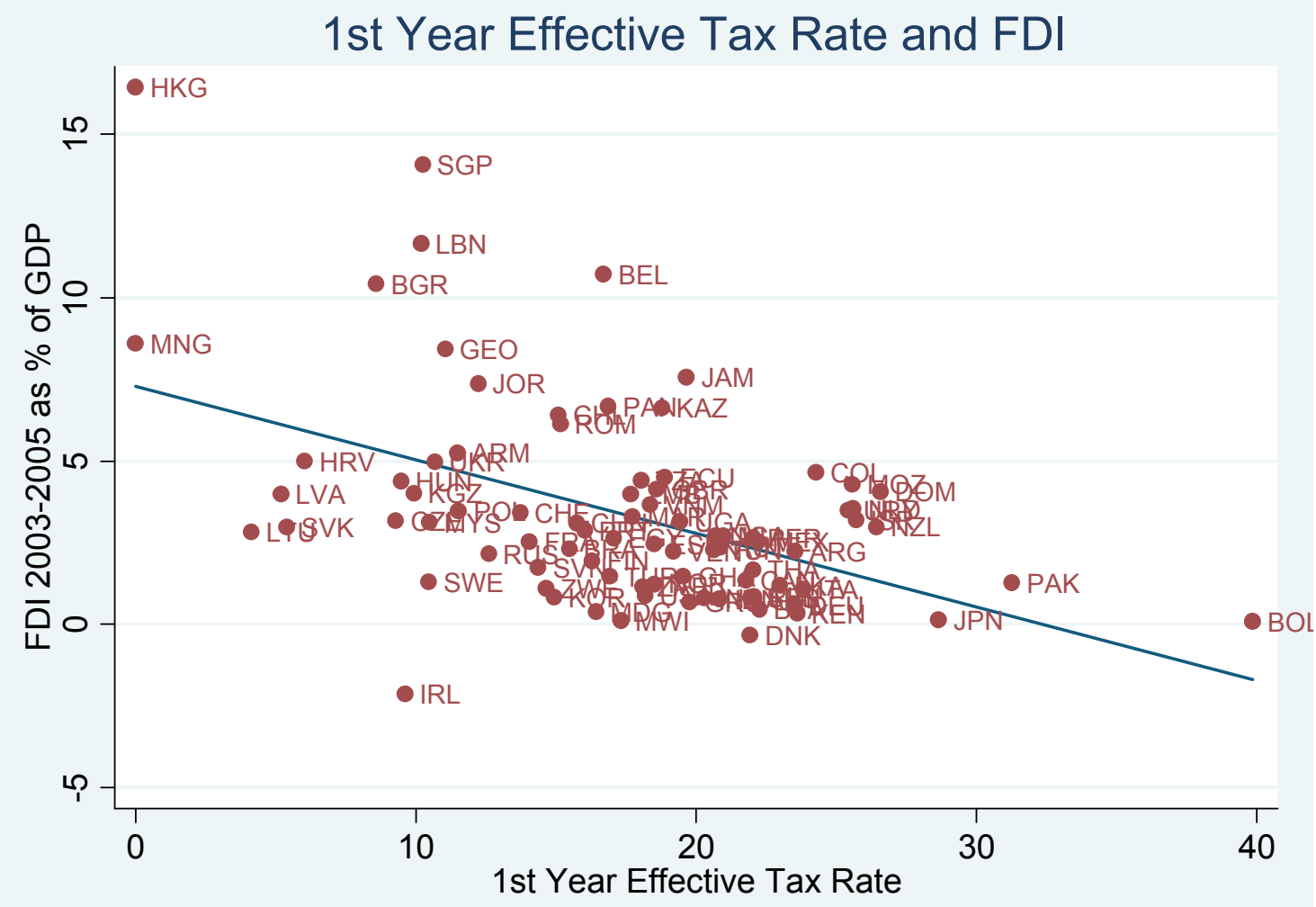


Figure 3

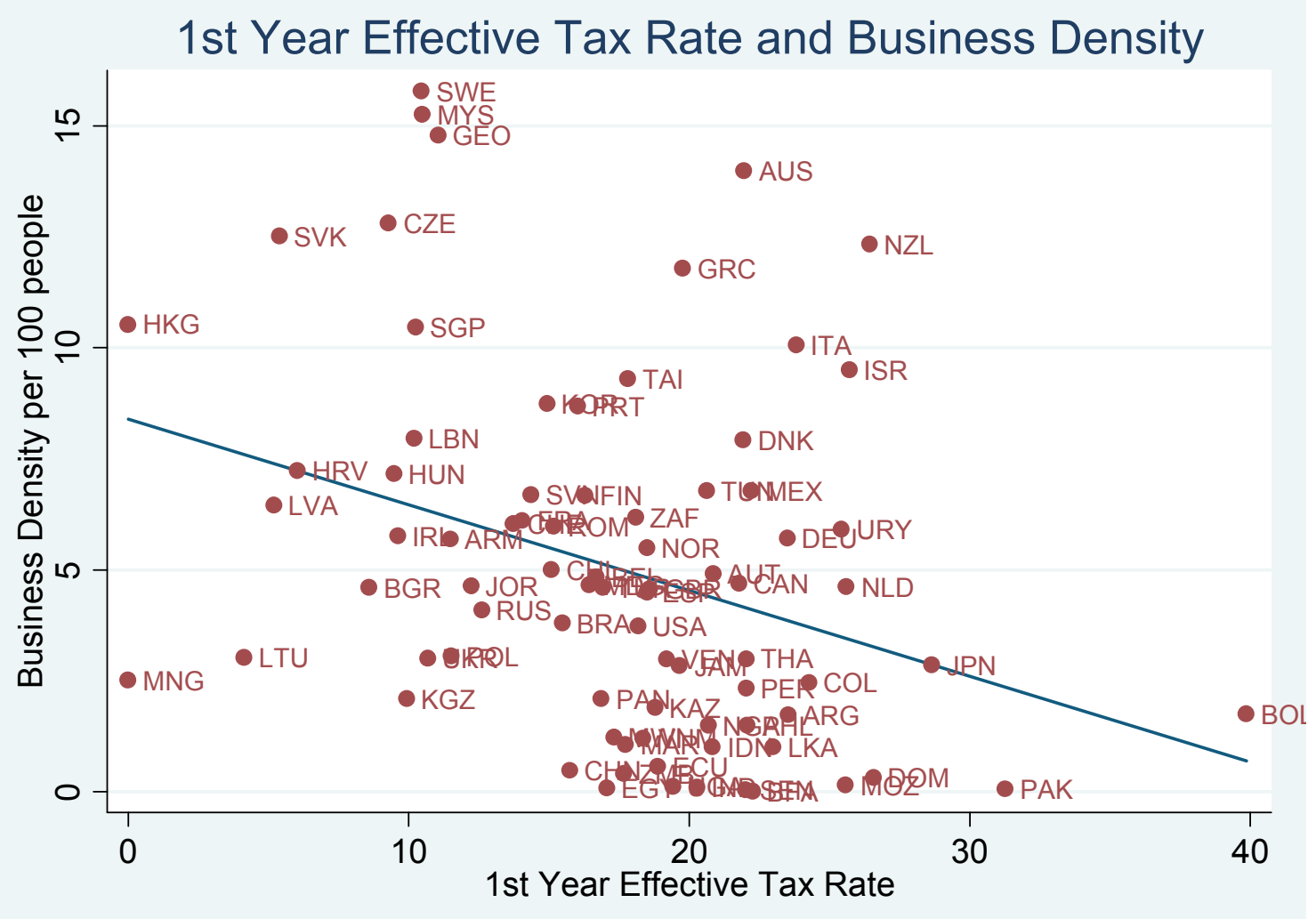

Figure 4

1st year effective tax rate and Entry rate

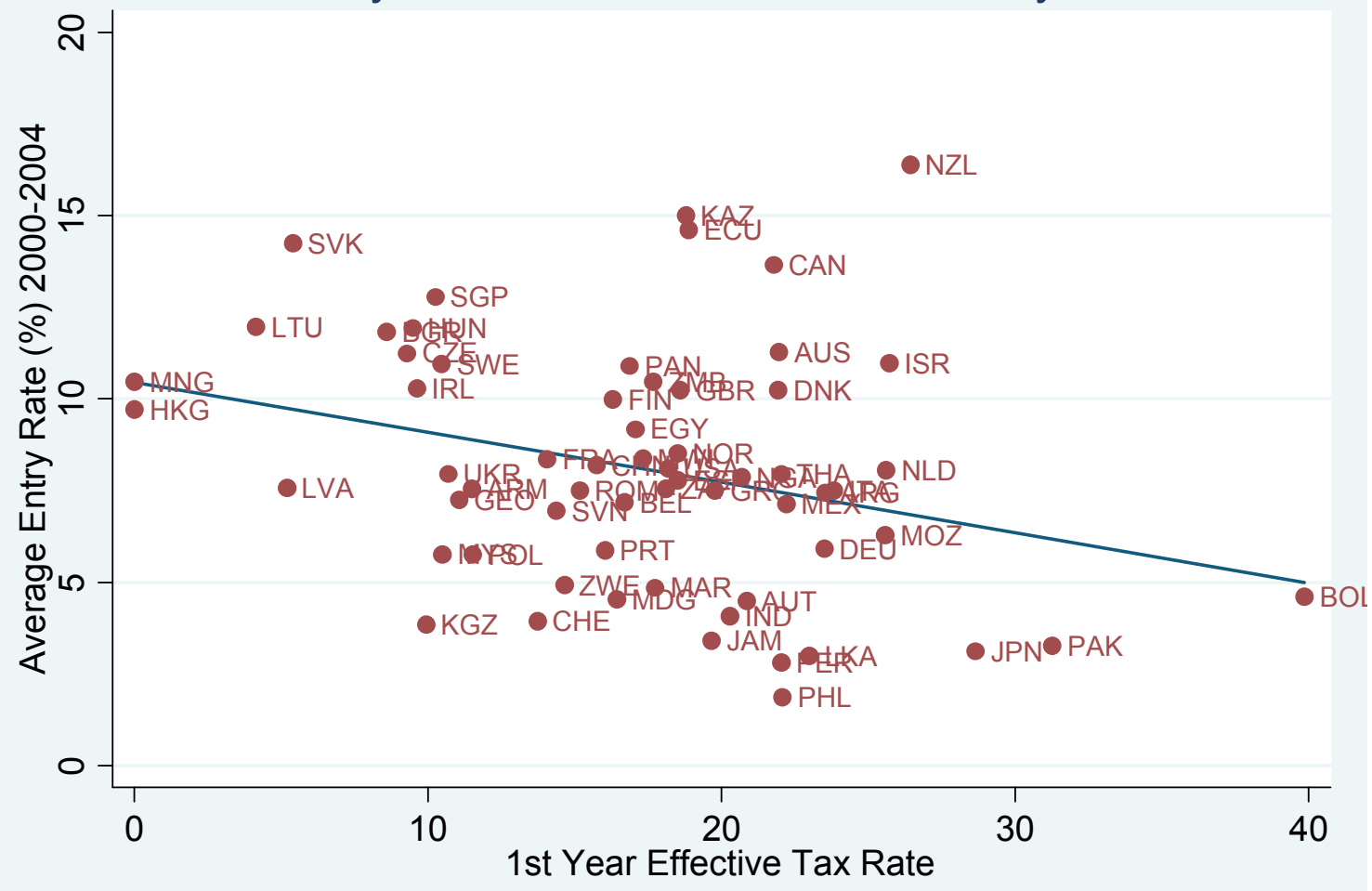


Figure 5

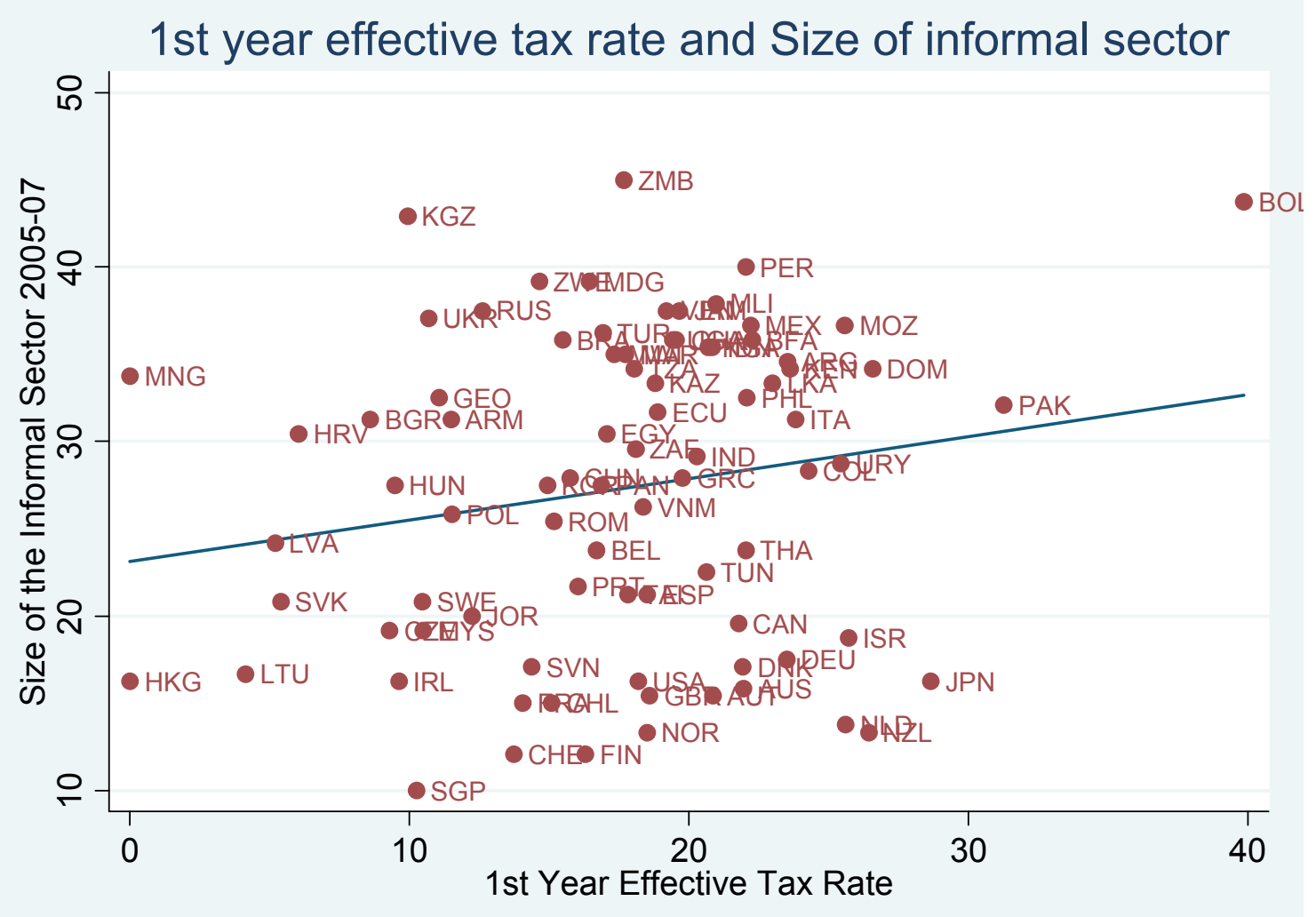

Figure 6

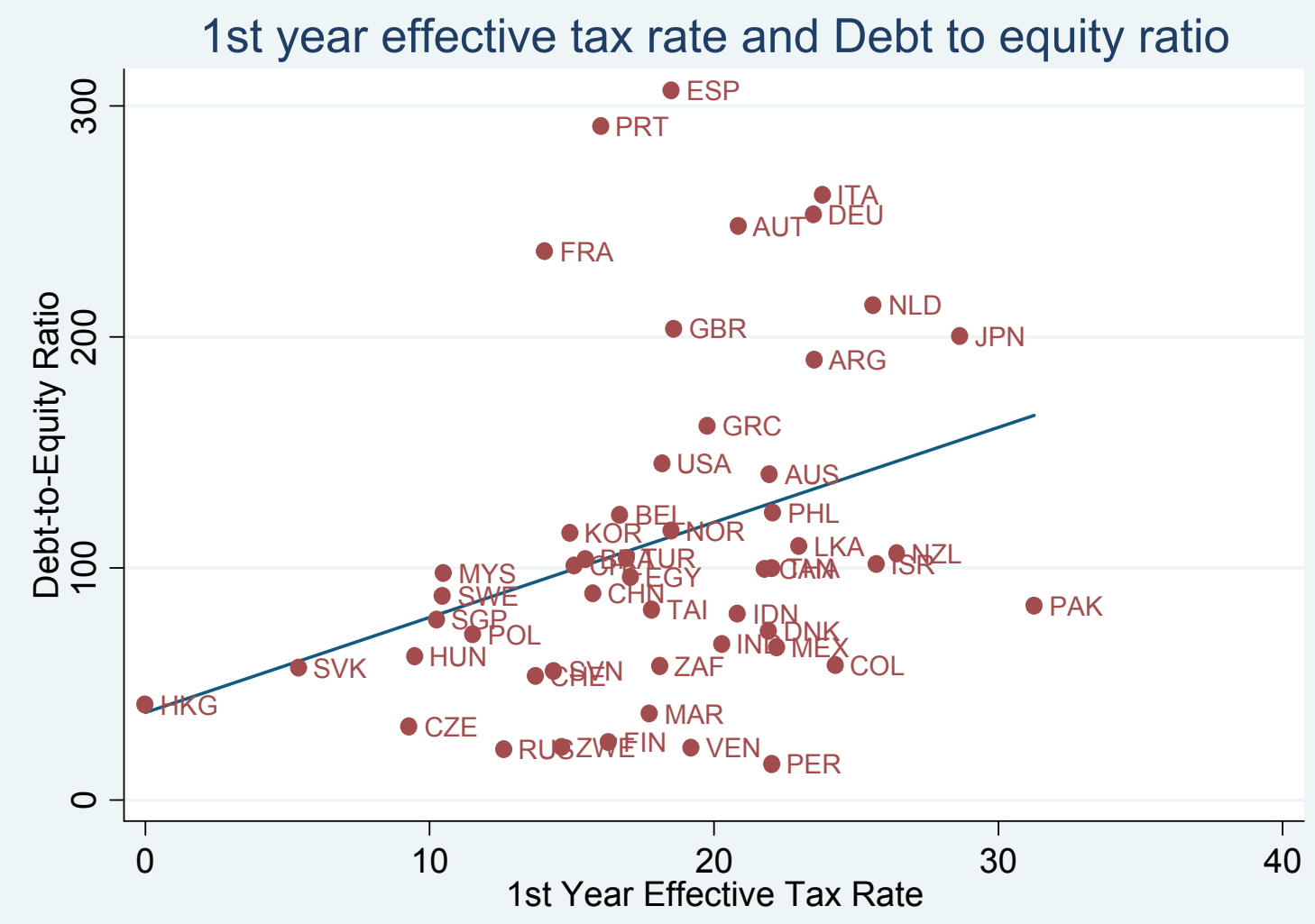


Appendix A

\begin{tabular}{|c|c|c|c|c|c|c|c|}
\hline Country & \begin{tabular}{|c|} 
Statutory \\
Corporate \\
Tax Rate
\end{tabular} & $\begin{array}{l}\text { 1st Year } \\
\text { Effective } \\
\text { Tax Rate }\end{array}$ & $\begin{array}{c}5 \text {-Year } \\
\text { Effective } \\
\text { Tax Rate }\end{array}$ & Labor Tax & Other Taxes & $\begin{array}{l}\text { VAT and } \\
\text { Sales Tax }\end{array}$ & Notes \\
\hline Argentina & 35.00 & 23.54 & 23.80 & 19.51 & 14.51 & 24.00 & \\
\hline Armenia & 20.00 & 11.48 & 12.46 & 16.00 & 0.53 & 20.00 & \\
\hline Australia & 30.00 & 21.96 & 23.03 & 11.38 & 0.24 & 10.00 & \\
\hline Austria & 34.00 & 20.86 & 21.04 & 25.11 & 0.19 & 20.00 & \\
\hline Belgium & 33.99 & 16.71 & 19.57 & 24.27 & 0.54 & 21.00 & \\
\hline Bolivia & 25.00 & 39.87 & 39.87 & 10.18 & 17.58 & 14.94 & 9,10 \\
\hline Brazil & 34.00 & 15.49 & 15.49 & 31.45 & 4.32 & 73.54 & \\
\hline Bulgaria & 19.50 & 8.60 & 10.24 & 26.36 & 1.02 & 20.00 & \\
\hline Burkina Faso & 35.00 & 22.28 & 22.54 & 13.99 & 4.07 & 18.00 & \\
\hline Canada & 36.12 & 21.78 & 25.93 & 7.04 & 4.52 & 15.00 & \\
\hline Chile & 17.00 & 15.09 & 15.09 & 2.04 & 2.17 & 19.00 & \\
\hline China & 33.00 & 15.75 & 15.75 & 36.71 & 0.88 & 18.87 & \\
\hline Colombia & 38.50 & 24.28 & 24.28 & 23.64 & 4.40 & 16.97 & \\
\hline Croatia & 20.06 & 6.04 & 11.90 & 14.16 & 0.00 & 22.07 & 1 \\
\hline Czech Republic & 28.00 & 9.29 & 13.00 & 29.68 & 0.02 & 19.00 & \\
\hline Denmark & 30.00 & 21.94 & 24.53 & 0.61 & 1.14 & 25.00 & \\
\hline Dominican Republic & 25.00 & 26.58 & 26.58 & 10.62 & 0.99 & 13.00 & 9,10 \\
\hline Ecuador & 25.00 & 18.90 & 19.08 & 10.30 & 0.77 & 12.00 & \\
\hline Egypt & 34.00 & 17.07 & 20.43 & 21.74 & 0.51 & 10.00 & 2 \\
\hline Finland & 29.00 & 16.30 & 18.84 & 18.04 & 0.73 & 22.00 & \\
\hline France & 35.43 & 14.06 & 14.42 & 37.65 & 3.32 & 21.10 & 9,11 \\
\hline Georgia & 20.00 & 11.06 & 11.06 & 26.29 & 1.36 & 20.50 & \\
\hline Germany & 37.07 & 23.50 & 23.60 & 16.75 & 0.04 & 16.00 & 3 \\
\hline Ghana & 35.00 & 19.55 & 22.48 & 10.60 & 0.01 & 13.54 & \\
\hline Greece & 35.00 & 19.78 & 19.91 & 23.80 & 0.21 & 18.00 & \\
\hline Hong Kong, China & 17.50 & 0.00 & 12.25 & 3.95 & 0.00 & 0.00 & \\
\hline Hungary & 18.00 & 9.48 & 9.62 & 31.01 & 5.26 & 27.20 & \\
\hline India & 36.59 & 20.28 & 24.29 & 14.21 & 3.28 & 25.65 & \\
\hline Indonesia & 30.00 & 20.84 & 21.01 & 8.00 & 0.09 & 10.00 & \\
\hline Ireland & 12.50 & 9.62 & 9.62 & 9.12 & 0.00 & 21.00 & \\
\hline Israel & 35.00 & 25.72 & 25.98 & 5.04 & 1.19 & 17.17 & \\
\hline Italy & 37.25 & 23.82 & 23.82 & 35.23 & 0.27 & 20.00 & \\
\hline Jamaica & 33.33 & 19.67 & 23.42 & 9.75 & 0.95 & 15.00 & \\
\hline Japan & 42.05 & 28.66 & 31.64 & 10.00 & 2.16 & 5.00 & 4 \\
\hline Jordan & 15.72 & 12.24 & 12.28 & 9.33 & 0.45 & 16.00 & 5 \\
\hline Kazakhstan & 30.00 & 18.79 & 20.62 & 14.96 & 1.69 & 15.00 & \\
\hline Kenya & 30.00 & 23.62 & 24.84 & 5.44 & 4.90 & 16.30 & \\
\hline Korea & 26.73 & 14.94 & 18.38 & 5.87 & 0.65 & 10.00 & \\
\hline Kyrgyz Republic & 20.00 & 9.94 & 11.88 & 21.20 & 0.44 & 26.30 & \\
\hline Latvia & 15.00 & 5.20 & 8.47 & 20.40 & 0.44 & 18.00 & \\
\hline Lebanon & 15.00 & 10.20 & 10.24 & 18.23 & 0.00 & 10.00 & \\
\hline Lithuania & 15.00 & 4.14 & 7.25 & 26.21 & 1.08 & 18.48 & \\
\hline Madagascar & 30.00 & 16.43 & 19.99 & 14.21 & 1.24 & 20.00 & 9,11 \\
\hline Malawi & 30.00 & 17.32 & 25.07 & 0.85 & 0.00 & 17.50 & 9,10 \\
\hline Malaysia & 28.00 & 10.50 & 16.13 & 9.79 & 0.35 & 10.00 & \\
\hline Mali & 35.00 & 20.97 & 21.23 & 17.73 & 3.33 & 18.00 & \\
\hline Mexico & 33.00 & 22.21 & 22.48 & 18.46 & 0.70 & 15.00 & 9,12 \\
\hline Mongolia & 30.00 & 0.00 & 6.63 & 15.27 & 0.30 & 15.00 & 6 \\
\hline Morocco & 35.00 & 17.74 & 22.33 & 16.71 & 0.27 & 20.00 & \\
\hline Mozambique & 32.00 & 25.59 & 25.59 & 3.39 & 1.35 & 17.00 & \\
\hline Netherlands & 34.50 & 25.62 & 25.62 & 12.90 & 0.50 & 19.00 & \\
\hline New Zealand & 33.00 & 26.44 & 28.45 & 0.00 & 0.12 & 12.50 & \\
\hline Nigeria & 32.00 & 20.69 & 21.99 & 6.54 & 0.40 & 5.00 & \\
\hline Norway & 28.00 & 18.50 & 20.33 & 11.96 & 0.00 & 24.00 & \\
\hline Pakistan & 41.00 & 31.28 & 32.42 & 9.77 & 0.53 & 15.00 & 9,11 \\
\hline Panama & 30.00 & 16.88 & 20.25 & 10.39 & 7.62 & 5.00 & \\
\hline Peru & 30.00 & 22.03 & 23.57 & 8.27 & 1.83 & 19.00 & \\
\hline Philippines & 32.00 & 22.08 & 22.88 & 7.24 & 3.14 & 10.68 & \\
\hline
\end{tabular}




\section{Appendix A}

\begin{tabular}{|l|r|r|r|r|r|r|r|}
\hline Country & $\begin{array}{c}\text { Statutory } \\
\text { Corporate } \\
\text { Tax Rate }\end{array}$ & $\begin{array}{c}\text { 1st Year } \\
\text { Effective } \\
\text { Tax Rate }\end{array}$ & $\begin{array}{c}\text { 5-Year } \\
\text { Effective } \\
\text { Tax Rate }\end{array}$ & Labor Tax & Other Taxes & $\begin{array}{c}\text { VAT and } \\
\text { Sales Tax }\end{array}$ & Notes \\
\hline Poland & 19.00 & 11.54 & 12.47 & 16.01 & 0.98 & 22.00 & \\
\hline Portugal & 27.50 & 16.03 & 16.10 & 20.07 & 0.71 & 19.00 & \\
\hline Romania & 25.00 & 15.17 & 15.35 & 27.35 & 0.53 & 19.00 & \\
\hline Russia & 24.00 & 12.62 & 12.98 & 29.41 & 2.30 & 18.00 & \\
\hline Senegal & 33.00 & 22.01 & 22.34 & 15.06 & 5.06 & 18.00 & 9,10 \\
\hline Singapore & 20.00 & 10.25 & 13.17 & 10.68 & 2.18 & 5.00 & \\
\hline Slovakia & 19.00 & 5.40 & 8.63 & 29.03 & 0.22 & 19.00 & \\
\hline Slovenia & 25.00 & 14.38 & 15.76 & 14.64 & 0.29 & 20.00 & \\
\hline South Africa & 30.00 & 18.10 & 22.69 & 1.99 & 2.01 & 14.14 & \\
\hline Spain & 35.00 & 18.52 & 18.61 & 33.23 & 0.18 & 16.00 & \\
\hline Sri Lanka & 32.50 & 23.00 & 23.09 & 12.72 & 1.66 & 16.00 & \\
\hline Sweden & 28.00 & 10.47 & 14.93 & 27.16 & 0.33 & 25.00 & \\
\hline Switzerland & 24.10 & 13.74 & 16.18 & 8.57 & 0.45 & 7.60 & 7 \\
\hline Taiwan, China & 25.00 & 17.83 & 18.01 & 7.73 & 1.87 & 5.00 & \\
\hline Tanzania & 30.00 & 18.05 & 20.69 & 13.57 & 0.08 & 20.30 & \\
\hline Thailand & 30.00 & 22.04 & 22.26 & 4.18 & 3.79 & 7.00 & \\
\hline Tunisia & 35.00 & 20.63 & 23.45 & 15.27 & 0.00 & 19.24 & \\
\hline Turkey & 30.00 & 16.92 & 16.92 & 22.96 & 0.34 & 18.00 & \\
\hline Uganda & 30.00 & 19.42 & 21.94 & 8.48 & 0.43 & 17.50 & \\
\hline Ukraine & 25.00 & 10.68 & 13.16 & 31.51 & 0.09 & 20.00 & \\
\hline United Kingdom & 30.00 & 18.61 & 21.44 & 8.19 & 1.10 & 17.50 & \\
\hline United States & 45.20 & 18.19 & 31.99 & 7.18 & 4.56 & 8.25 & 8 \\
\hline Uruguay & 30.00 & 25.45 & 25.53 & 3.07 & 0.00 & 26.00 & \\
\hline Venezuela & 34.00 & 19.21 & 19.72 & 13.32 & 2.80 & 16.48 & \\
\hline Vietnam & 28.00 & 18.37 & 18.79 & 14.42 & 0.17 & 10.00 & \\
\hline Zambia & 35.00 & 17.68 & 25.32 & 4.24 & 0.00 & 17.50 & \\
\hline Zimbabwe & 30.90 & 14.66 & 20.23 & 3.52 & 4.87 & 15.00 & 9 \\
\hline
\end{tabular}

Notes The Statutory Corporate Tax Rate includes all levies on corporate income (and also those that are levied on the corporate income tax itself).

1 There exists a Forest Contribution on Earnings before Taxes which is deductible both from its own tax base and from the tax base for the Corporate Income Tax.

2 The State Development Duty on Earnings before Taxes in excess of EGP 18,000, which is technically deductible from the tax base for the Corporate Income Tax. However, the tax authorities did not allow this deduction.

3 The Trade Tax is deductible both from its own tax base and from the tax base for the Corporate Income Tax.

4 The Enterprise Tax on Earnings before Taxes is deductible from its own tax base and that of the Corporate Income Tax.

5 The Contribution to the education and vocational training support fund is deductible from the tax base for the Corporate Income Tax.

6 There is an exemption from the Corporate Income Tax in the first year of a company's operations.

7 The Corporate Income Tax is deductible from its own tax base.

8 The New York City corporation franchise tax is deductible both in the tax base of the New York state corporation franchise tax and of the Federal Corporate Income Tax. The New York state corporation franchise tax is deductible in the tax base of the Federal Corporate Income Tax.

9 There exists a Minimum Tax.

10 The Minimum Tax applies.

11 The Minimum Tax does not apply.

12 There is an exemption from the Minimum Tax for the first three years. 


\section{Appendix B}

Using the example of Argentina, the following is a description of how we obtained the tax measures " 1 st Year Effective Corporate Tax Rate" and "5-Year Effective Corporate Tax Rate".

The statutory corporate income tax rate in Argentina is a single rate of 35\%. The Social Security Contributions paid by the employer are $23 \%$ total. The tax base for the Social Security Contributions is the employee's gross salary with a ceiling (which is not binding for TaxpayerCo.) The Social Security Contributions are deductible from the tax base for the corporate income tax. Depreciation rates are as follows: Land - not depreciable; Building - 2\% straight-line; Machinery - 10\% straight-line; Truck - 20\% straight-line; Computers - 33.33\% straight-line; Office Equipment - 20\% straight-line. Advertising, interest, and machinery repair expenses are deductible in the tax base for the corporate income tax.

We calculate the Labor Tax liability of TaxpayerCo as shown in Table A:

Table A - Labor Tax Calculations

\begin{tabular}{|c|c|c|}
\hline \multicolumn{3}{|l|}{ Managers: } \\
\hline Total annual salaries for the 4 managers & $9 *$ GNI per capita $=$ & 95,808 \\
\hline Monthly salaries & $95,808 /(12 * 4)=$ & 1,996 \\
\hline Monthly Soc. Sec. Contr. & $23 \% * 1,996=$ & 459 \\
\hline Yearly Soc. Sec. Contr. per manager & $12 * 459=$ & 5,509 \\
\hline Total annual Soc. Sec. Contr. for the 4 managers & $4 * 5,509=$ & 22,036 \\
\hline \multicolumn{3}{|l|}{ Assistants: } \\
\hline Total annual salaries for the 8 assistants & $10 * \mathrm{GNI}$ per capita $=$ & 106,453 \\
\hline Monthly salaries & $106,453 /(12 * 8)=$ & 1,109 \\
\hline Monthly Soc. Sec. Contr. & $23 \% * 1,109=$ & 255 \\
\hline Yearly Soc. Sec. Contr. per manager & $12 * 255=$ & 3,061 \\
\hline Total annual Soc. Sec. Contr. for the 8 assistants & $8 * 3,061=$ & 24,484 \\
\hline \multicolumn{3}{|l|}{ Workers: } \\
\hline Total annual salaries for the 48 workers & $48^{*}$ GNI per capita $=$ & 510,975 \\
\hline Monthly salaries & $510,975 /(12 * 48)=$ & 887 \\
\hline Monthly Soc. Sec. Contr. & $23 \% * 887=$ & 204 \\
\hline Yearly Soc. Sec. Contr. per manager & $12 * 204=$ & 2,448 \\
\hline Total annual Soc. Sec. Contr. for the 48 workers & $48 * 2,448=$ & 117,524 \\
\hline
\end{tabular}


The depreciation allowances for the first five years are calculated as shown in Table B:

Table B - Calculation of Depreciation Allowances

\begin{tabular}{|l|r|r|r|r|r|}
\cline { 2 - 5 } \multicolumn{1}{c|}{} & \multicolumn{1}{c|}{ Year 1 } & \multicolumn{1}{c|}{ Year 2 } & \multicolumn{1}{c|}{ Year 3 } & \multicolumn{1}{c|}{ Year 4 } & \multicolumn{1}{c|}{ Year 5 } \\
\hline Building (40*GNI per capita) & 425,812 & 417,296 & 408,780 & 400,264 & 391,747 \\
\cline { 2 - 5 } Annual Depreciation (2\% straight line) & 8,516 & 8,516 & 8,516 & 8,516 & 8,516 \\
\cline { 2 - 6 } Net Property & 417,296 & 408,780 & 400,264 & 391,747 & 383,231 \\
\hline Machinery (60*GNI per capita) & 638,719 & 574,847 & 510,975 & 447,103 & 383,231 \\
\hline Annual Depreciation (10\% straight line) & 63,872 & 63,872 & 63,872 & 63,872 & 63,872 \\
\cline { 2 - 6 } Net Machinery & 574,847 & 510,975 & 447,103 & 383,231 & 319,359 \\
\hline Truck (5*GNI per capita) & 53,227 & 42,581 & 31,936 & 21,291 & 10,645 \\
\hline Annual Depreciation (20\% straight line) & 10,645 & 10,645 & 10,645 & 10,645 & 10,645 \\
\cline { 2 - 6 } Net Machinery & 42,581 & 31,936 & 21,291 & 10,645 & - \\
\hline Computers (5*GNI per capita) & 53,227 & 35,484 & 17,742 & & - \\
\cline { 2 - 5 } Annual Depreciation (33.33\% straight line) & 17,742 & 17,742 & 17,742 & & - \\
\cline { 2 - 6 } Net Machinery & 35,484 & 17,742 & & - & \\
\hline Office Equipment (5*GNI per capita) & 53,227 & 42,581 & 31,936 & 21,291 & 10,645 \\
\cline { 2 - 6 } Annual Depreciation (20\% straight line) & 10,645 & 10,645 & 10,645 & 10,645 & 10,645 \\
\cline { 2 - 6 } & 42,581 & 31,936 & 21,291 & 10,645 & - \\
\hline Net Machinery & $\mathbf{1 1 1 , 4 2 1}$ & $\mathbf{1 1 1 , 4 2 1}$ & $\mathbf{1 1 1 , 4 2 1}$ & $\mathbf{9 3 , 6 7 9}$ & $\mathbf{9 3 , 6 7 9}$ \\
\hline Total Depreciation Allowance & & & & \\
\hline
\end{tabular}

The Labor Tax liability, which as stated above is deductible in the Corporate Income Tax base, and the Depreciation Allowance are then used in the calculation of the Corporate Income Tax liability, which we calculate as shown in Table C: 
Table C - Income Statement

\begin{tabular}{|l|r|r|r|r|r|}
\cline { 2 - 5 } \multicolumn{1}{c|}{} & \multicolumn{1}{c|}{ Year 1 } & \multicolumn{1}{c|}{ Year 2 } & \multicolumn{1}{c|}{ Year 3 } & \multicolumn{1}{c|}{ Year 4 } & \multicolumn{1}{c|}{ Year 5 } \\
\hline Sales (=1050*GNI p.c.) & $11,177,578$ & $11,177,578$ & $11,177,578$ & $11,177,578$ & $11,177,578$ \\
\hline Cost of Goods Sold (=875*GNI p.c.) & $9,314,648$ & $9,314,648$ & $9,314,648$ & $9,314,648$ & $9,314,648$ \\
\hline Operating Expenses (=77*GNI p.c.) & 819,689 & 819,689 & 819,689 & 819,689 & 819,689 \\
\hline Labor Taxes (as calculated above) & 164,044 & 164,044 & 164,044 & 164,044 & 164,044 \\
\hline $\begin{array}{l}\text { Other Possible Deductions (i.e. } \\
\text { advertising expenses at 10.5 GNI p.c. and } \\
\text { machinery repair expenses at 4*GNI p.c.) }\end{array}$ & 143,712 & 143,712 & 143,712 & 143,712 & 143,712 \\
\hline EBITDA & 735,485 & 735,485 & 735,485 & 735,485 & 735,485 \\
\hline $\begin{array}{l}\text { Depreciation and Amortization (as } \\
\text { calculated above) }\end{array}$ & 111,421 & 111,421 & 111,421 & 93,679 & 93,679 \\
\hline EBIT & 624,064 & 624,064 & 624,064 & 641,806 & 641,806 \\
\hline Interest Expense (=5.5*GNI p.c.) & 58,549 & 58,549 & 58,549 & 58,549 & 58,549 \\
\hline Earnings before Taxes & 565,514 & 565,514 & 565,514 & 583,257 & 583,257 \\
\hline Income Tax & $\mathbf{1 9 7 , 9 3 0}$ & $\mathbf{1 9 7 , 9 3 0}$ & $\mathbf{1 9 7 , 9 3 0}$ & $\mathbf{2 0 4 , 1 4 0}$ & $\mathbf{2 0 4 , 1 4 0}$ \\
\hline Net Income & 367,584 & $\mathbf{3 6 7 , 5 8 4}$ & 367,584 & 379,117 & 379,117 \\
\hline $\begin{array}{l}\text { PDV of Income Tax (at an 8\% } \\
\text { discount rate) }\end{array}$ & $\mathbf{1 9 7 , 9 3 0}$ & $\mathbf{1 8 3 , 2 6 9}$ & $\mathbf{1 6 9 , 6 9 3}$ & $\mathbf{1 6 2 , 0 5 3}$ & $\mathbf{1 5 0 , 0 4 9}$ \\
\hline
\end{tabular}

With this information the $1^{\text {st }}$ year effective corporate tax rate and the 5-year effective corporate tax rate are calculated as follows:

- The $1^{\text {st }}$ year effective corporate tax rate is simply the Year 1 income tax liability divided by the denominator (i.e. 79 times GNI per capita), which in Argentina's case works out to be $(197,930 / 840,980=) 23.54 \%$.

- The 5-year effective corporate tax rate is simply the sum of the present-discounted values of the income tax liability in years 1 to 5 divided by sum of the present-discounted values of the denominator in years 1 to 5 (which does not change in absolute terms but does change in PDV terms). In Argentina's case, this works out to be $(862,993 / 3,626,411=)$ $23.80 \%$. 


\section{Appendix C}

\section{Sample 1 - Countries with the same tax regime regardless of legal form}

Argentina, Armenia, Austria, Belgium, Brazil, Bulgaria, Chile, Colombia, Croatia, Denmark, Dominican Republic, Ecuador, Egypt, Germany, Hong Kong, China, Hungary, Indonesia, Ireland, Italy, Jamaica, Japan, Jordan, Korea, Latvia, Lebanon, Lithuania, Malaysia, Mexico, Mongolia, Morocco, Mozambique, Netherlands, Nigeria, Panama, Peru, Philippines, Portugal, Romania, Russia, Slovakia, South Africa, Spain, Switzerland, Taiwan, China, Thailand, Tunisia, Turkey, United Kingdom, Uruguay, Vietnam

\section{Sample 2 - Countries with different tax regimes depending on legal form}

Australia, Canada, China, Finland, France, Ghana, Greece, Kenya, Kyrgyz Republic, New Zealand, Norway, Singapore, Sri Lanka, Sweden, Tanzania, Uganda, United States, Venezuela, Zambia

\section{Countries for which we do not have information on how the legal form affects the tax regime}

Bolivia, Burkina Faso, Czech Republic, Georgia, India, Israel, Kazakhstan, Madagascar, Malawi, Mali, Pakistan, Poland, Senegal, Slovenia, Ukraine, Zimbabwe

\section{Basic regression restricted to Sample 1}

\begin{tabular}{|c|c|c|c|c|c|c|}
\hline & \multicolumn{6}{|c|}{ Panel A - Investment } \\
\hline & $(1)$ & $(2)$ & (3) & $(4)$ & $(5)$ & (6) \\
\hline & \multicolumn{3}{|c|}{ Investment 2003-05 } & \multicolumn{3}{|c|}{ FDI 2003-05 } \\
\hline Statutory Corporate Tax Rate & $\begin{array}{c}-0.129 \\
(0.086)\end{array}$ & & & $\begin{array}{r}-0.160^{* *} \\
(0.063)\end{array}$ & & \\
\hline 1st Year Effective Tax Rate & & $\begin{array}{r}-0.237^{* * *} \\
(0.086)\end{array}$ & & & $\begin{array}{r}-0.229^{* * *} \\
(0.062)\end{array}$ & \\
\hline 5-Year Effective Tax Rate & & & $\begin{array}{r}-0.250^{* *} \\
(0.101)\end{array}$ & & & $\begin{array}{r}-0.211^{* * *} \\
(0.075)\end{array}$ \\
\hline Constant & $\begin{array}{r}25.332^{* * *} \\
(2.473)\end{array}$ & $\begin{array}{r}25.683^{* * *} \\
(1.547)\end{array}$ & $\begin{array}{r}26.345^{\star \star *} \\
(1.954)\end{array}$ & $\begin{array}{r}8.356^{* * *} \\
(1.802)\end{array}$ & $\begin{array}{r}7.717^{* * *} \\
(1.107)\end{array}$ & $\begin{array}{r}7.796^{* * *} \\
(1.455)\end{array}$ \\
\hline Observations & 50 & 50 & 50 & 49 & 49 & 49 \\
\hline \multirow[t]{4}{*}{ R-squared } & 0.04 & 0.14 & 0.11 & 0.12 & 0.23 & 0.14 \\
\hline & \multicolumn{6}{|c|}{ Panel B - Entrepreneurship } \\
\hline & $(1)$ & $(2)$ & $(3)$ & $(4)$ & $(5)$ & (6) \\
\hline & \multicolumn{3}{|c|}{ Business Density } & \multicolumn{3}{|c|}{ Average entry rate $2000-04$} \\
\hline Statutory Corporate Tax Rate & $\begin{array}{r}-0.139^{* *} \\
(0.062)\end{array}$ & & & $\begin{array}{r}-0.227^{* * *} \\
(0.063)\end{array}$ & & \\
\hline 1st Year Effective Tax Rate & & $\begin{array}{r}-0.189^{* * *} \\
(0.063)\end{array}$ & & & $\begin{array}{r}-0.211^{* * *} \\
(0.063)\end{array}$ & \\
\hline 5-Year Effective Tax Rate & & & $\begin{array}{r}-0.191^{* *} \\
(0.074)\end{array}$ & & & $\begin{array}{r}-0.273^{* * *} \\
(0.072)\end{array}$ \\
\hline Constant & $\begin{array}{r}8.792^{* \star *} \\
(1.779)\end{array}$ & $\begin{array}{r}8.071^{* * *} \\
(1.128)\end{array}$ & $\begin{array}{r}8.447^{* * *} \\
(1.438)\end{array}$ & $\begin{array}{r}14.314^{* * *} \\
(1.841)\end{array}$ & $\begin{array}{r}11.325^{\star \star *} \\
(1.138)\end{array}$ & $\begin{array}{r}12.921^{* * *} \\
(1.403)\end{array}$ \\
\hline ations & 50 & 50 & 50 & 35 & 35 & 35 \\
\hline R-squared & 0.09 & 0.16 & 0.12 & 0.28 & 0.25 & 0.30 \\
\hline
\end{tabular}




\section{Appendix C}

\section{Basic regression restricted to Sample 2}

\begin{tabular}{lrrrrrr} 
& \multicolumn{7}{c}{ Panel A - Investment } \\
& \multicolumn{1}{c}{$(1)$} & $(2)$ & $(3)$ & $(4)$ & \multicolumn{1}{c}{$(5)$} & $(6)$ \\
\hline & \multicolumn{7}{c}{ Investment 2003-05 } & \multicolumn{1}{c}{ FDI 2003-05 } \\
\hline Statutory Corporate Tax Rate & 0.194 & & & $-0.297^{* *}$ \\
& $(0.245)$ & & & $(0.107)$ & \\
1st Year Effective Tax Rate & & 0.188 & & & $-0.336^{* *}$ \\
& & $(0.307)$ & & & $(0.138)$ \\
5-Year Effective Tax Rate & & & -0.008 & & & $-0.248^{*}$ \\
& & & $(0.266)$ & & & $(0.124)$ \\
Constant & $15.594^{*}$ & $18.307^{* * *}$ & $21.874^{* * *}$ & $12.069^{* * *}$ & $8.797^{* * *}$ & $7.882^{* * *}$ \\
& $(7.840)$ & $(5.722)$ & $(5.728)$ & $(3.427)$ & $(2.578)$ & $(2.667)$ \\
Observations & 19 & 19 & 19 & 19 & 19 & 19 \\
R-squared & 0.04 & 0.02 & 0.00 & 0.31 & 0.26 & 0.19 \\
\hline
\end{tabular}

(1)

Panel B - Entrepreneurship

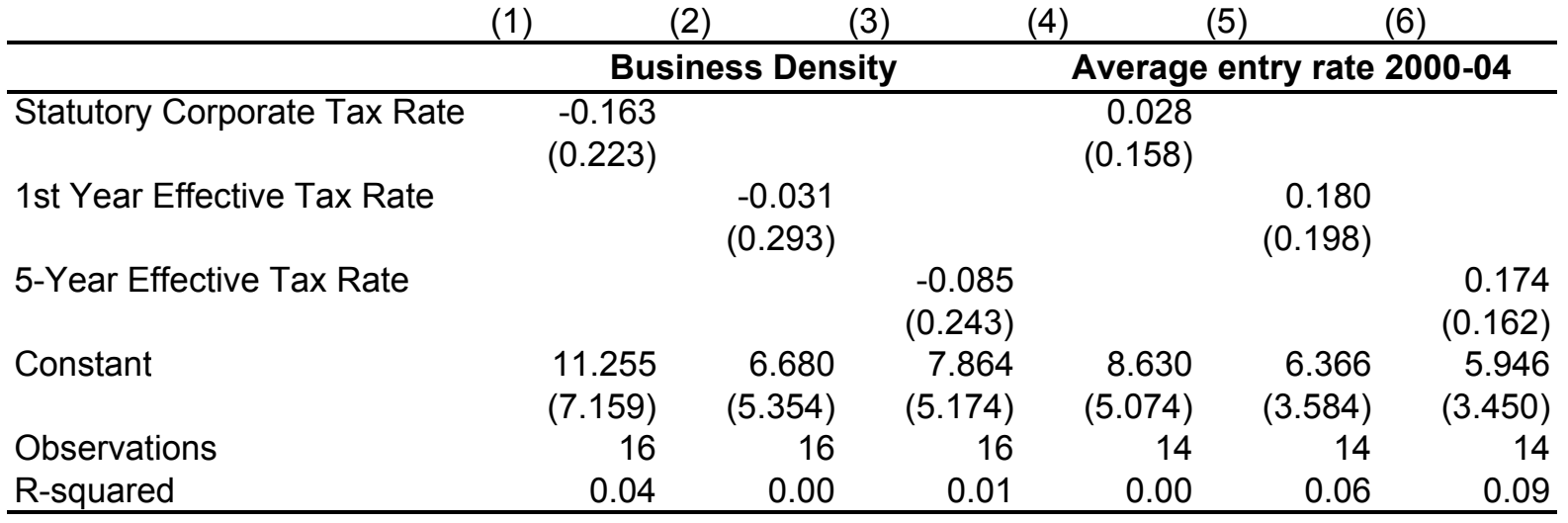




\section{Appendix C}

\section{Basic regression restricted to Sample 3}

\begin{tabular}{|c|c|c|c|c|c|c|}
\hline & \multicolumn{6}{|c|}{ Panel A - Investment } \\
\hline & (1) & (2) & (3) & (4) & (5) & (6) \\
\hline & \multicolumn{3}{|c|}{ Investment 2003-05 } & \multicolumn{3}{|c|}{ FDI 2003-05 } \\
\hline Statutory Corporate Tax Rate & $\begin{array}{r}-0.070 \\
(0.200)\end{array}$ & & & $\begin{array}{c}-0.191^{*} \\
(0.096)\end{array}$ & & \\
\hline 1st Year Effective Tax Rate & & $\begin{array}{r}-0.300^{* *} \\
(0.126)\end{array}$ & & & $\begin{array}{l}-0.139^{*} \\
(0.072)\end{array}$ & \\
\hline 5-Year Effective Tax Rate & & & $\begin{array}{r}-0.372^{* \star *} \\
(0.125)\end{array}$ & & & $\begin{array}{r}-0.188^{* *} \\
(0.070)\end{array}$ \\
\hline Constant & $\begin{array}{r}22.335^{\star * *} \\
(6.080)\end{array}$ & $\begin{array}{r}26.003^{* * *} \\
(2.609)\end{array}$ & $\begin{array}{r}28.150^{* * *} \\
(2.803)\end{array}$ & $\begin{array}{l}8.155^{\star *} \\
(2.912)\end{array}$ & $\begin{array}{r}5.123^{* * *} \\
(1.483)\end{array}$ & $\begin{array}{r}6.449^{* * *} \\
(1.574)\end{array}$ \\
\hline Observations & 16 & 16 & 16 & 16 & 16 & 16 \\
\hline R-squared & 0.01 & 0.29 & 0.39 & 0.22 & 0.21 & 0.34 \\
\hline
\end{tabular}

(1)

(2)

Panel B - Entrepreneurship

\begin{tabular}{|c|c|c|c|c|c|c|}
\hline & (1) & (2) & (3) & (4) & (5) & (6) \\
\hline & \multicolumn{3}{|c|}{ Business Density } & \multicolumn{3}{|c|}{ Average entry rate $2000-04$} \\
\hline Statutory Corporate Tax Rate & $\begin{array}{r}-0.353 \\
(0.199)\end{array}$ & & & $\begin{array}{c}-0.058 \\
(0.163)\end{array}$ & & \\
\hline 1st Year Effective Tax Rate & & $\begin{array}{l}-0.263^{*} \\
(0.146)\end{array}$ & & & $\begin{array}{r}-0.105 \\
(0.110)\end{array}$ & \\
\hline 5-Year Effective Tax Rate & & & $\begin{array}{l}-0.314^{*} \\
(0.148)\end{array}$ & & & $\begin{array}{l}-0.121 \\
(0.116)\end{array}$ \\
\hline Constant & $\begin{array}{r}14.655^{\star *} \\
(5.993)\end{array}$ & $\begin{array}{l}9.345^{\star *} \\
(3.065)\end{array}$ & $\begin{array}{r}10.945^{\star \star *} \\
(3.354)\end{array}$ & $\begin{array}{c}8.978^{*} \\
(4.806)\end{array}$ & $\begin{array}{r}9.259^{* * *} \\
(2.260)\end{array}$ & $\begin{array}{r}9.845^{\star \star \star} \\
(2.614)\end{array}$ \\
\hline Observations & 14 & 14 & 14 & 13 & 13 & 13 \\
\hline R-squared & 0.21 & 0.21 & 0.27 & 0.01 & 0.08 & 0.09 \\
\hline
\end{tabular}

Standard errors in parentheses

${ }^{*}$ significant at $10 \%$; ${ }^{* *}$ significant at $5 \%$; ${ }^{* * *}$ significant at $1 \%$ 


\section{Appendix D}

\section{FDI Regressions using OECD data}

Basic regressions, no control

\begin{tabular}{llll} 
& \multicolumn{1}{c}{$(1)$} & \multicolumn{1}{c}{$(2)$} \\
\hline & \multicolumn{3}{c}{ OECD FDI 2002-2004 } \\
\hline Statutory Corporate Tax Rate & $-0.248^{* * *}$ & \\
& $(0.069)$ & & \\
1st Year Effective Tax Rate & & $-0.277^{* * *}$ \\
& & $(0.090)$ & \\
5-Year Effective Tax Rate & & & $-0.268^{* * *}$ \\
& & & $(0.083)$ \\
Constant & $10.525^{* * *}$ & $7.874^{* * *}$ & $8.250^{* * *}$ \\
& $(2.144)$ & $(1.672)$ & $(1.717)$ \\
Observations & 28 & 28 & 28 \\
R-squared & 0.33 & 0.27 & 0.28 \\
\hline
\end{tabular}

\section{Controlling for Tax Evasion}

\begin{tabular}{|c|c|c|c|}
\hline & (1) & (2) & (3) \\
\hline & \multicolumn{3}{|c|}{ OECD FDI 2002-2004 } \\
\hline Statutory Corporate Tax Rate & $\begin{array}{l}-0.257^{* * *} \\
(0.072)\end{array}$ & & \\
\hline 1st Year Effective Tax Rate & & $\begin{array}{l}-0.295^{\star * *} \\
(0.096)\end{array}$ & \\
\hline 5-Year Effective Tax Rate & & & $\begin{array}{l}-0.317^{* * *} \\
(0.093)\end{array}$ \\
\hline Tax evasion (GCR) & $\begin{array}{l}0.223 \\
(0.474)\end{array}$ & $\begin{array}{l}0.290 \\
(0.507)\end{array}$ & $\begin{array}{l}0.602 \\
(0.523)\end{array}$ \\
\hline Constant & $\begin{array}{l}9.934^{* * *} \\
(2.515)\end{array}$ & $\begin{array}{l}7.074^{* * *} \\
(2.198)\end{array}$ & $\begin{array}{l}6.899^{* * *} \\
(2.072)\end{array}$ \\
\hline Observations & 28 & 28 & 28 \\
\hline R-squared & 0.34 & 0.28 & 0.32 \\
\hline
\end{tabular}

Note: No matter which of our controls we include, the coefficients on the tax rates always remain negative and highly significant (always significant at least at the $5 \%$ level and in the vast majority of the cases at the $1 \%$ level). 